SECONDARY SUITES: A METHODOLOGICAL APPROACH TO ESTIMATE THEIR PREVALANCE WITHIN THE CITY OF TORONTO

by

Jeremy Kloet

B.A. Specialization in Urban Planning, Concordia University, 2010

Dip. Applied Urban and Rural Planning, Langara College, 2007

A Master Research Paper
Presented to Ryerson University

In partial fulfillment of the

requirements of the degree of

Master of Planning

In the program of

Urban Development

Toronto, Ontario, Canada, 2013

(C) Jeremy Kloet 2013 


\section{AUTHOR'S DECLARATION FOR ELECTRONIC SUBMISSION OF A MRP}

I hereby declare that I am the sole author of this MRP. This is a true copy of the MRP, including any required final revisions, as accepted by my examiners.

I authorize Ryerson University to lend this MRP to other institutions or individuals for the purpose of scholarly research

I further authorize Ryerson University to reproduce this MRP by photocopying or by other means, in total or in part, at the request of other institutions or individuals for the purpose of scholarly research.

I understand that my MRP may be made electronically available to the public. 


\title{
SECONDARY SUITES: A METHODOLOGICAL APPROACH TO ESTIMATE THEIR PREVALANCE WITHIN THE CITY OF TORONTO
}

\author{
CJeremy Kloet, 2013 \\ Master of Planning \\ in \\ Urban Development \\ Ryerson University
}

\begin{abstract}
With the introduction of Bill 140 - Strong Communities Through Affordable Housing Act, one increasingly popular housing typology is secondary suites. However, their role within local housing markets has never been fully substantiated, numerically or functionally, Over the past decade, government agencies have employed a variety of techniques to estimate the number of secondary suites within local housing markets. However, due to a number of inherent limitations associated with available data sources and collection techniques, accurately estimated their prevalence is difficult because many secondary suites are not reported. As such, most data sources do not provide a complete estimate. In an effort to overcome these limitations, the following research paper has employed a methodological approach that combined MPAC data with visual surveys. The results of this approach will help provide a more accurate picture of the entire secondary suite rental market, identifying both reported and unreported units within Toronto.
\end{abstract}

\section{Keywords:}

Secondary suites, secondary rental housing market 


\section{Acknowledgments}

I would like to first and foremost thank my supervisors Dr. Joseph Springer and David Spence for their continued guidance and support. Without their knowledge, valued feedback, and constructive criticism much of what has been accomplished within this research paper would not have been possible.

I would like to thank Ryerson University and the Social Sciences and Humanities Research Council of Canada (SSHRC) for providing much need financial support throughout my graduate studies.

Lastly, many thanks to all my classmates and colleagues at Ryerson University, Concordia University and Langara Collage. They have all provided much needed inspiration and support. 


\section{Dedication}

I would like to didicate this Masters Research Paper to my family and friends. Thank you for helping me through this journey. 
Overview

Definition 1

Study Purpose 2

Research Questions 3

Toronto' Rental Housing Market 4

Ontario Legislative Framework 7

Chapter \#2: Benefits, Impacts and the Role of Secondary Suites 10

Overview 10

Benefits 10

Real and Perceived Impacts of Secondary Suites 12

Current and Potential Role within the Housing Market 13 Issues and Concerns

Chapter \#3: Review of the Estimation Techniques

Overview 16

The City of Toronto Property Assessment Rolls 16

CMHC's Secondary Rental Market Report (SRMS) 17

Multiple Listing Services (MLS) 19

City of Toronto Building Permits 20

Newspaper Advertisements

Telephone Lines 21

Water Meters 22

Other Techniques

Summary

Chapter \#4: Methodological Approach

Overview

Step \#1: Identify Neighbourhood Study Areas 25

Step \#2: Create A Property Database for each Study Area 25

Step \#3: Identify relevant MPAC property codes 25

Step \#4: Identify relevant MPAC structure codes 26

Step \#5: Select Additional MPAC variables 27

Step \#6: Record Assessment Data for Each Address 27

Step \#7: identifying reported Converted Structures 27 
Step \#8: Identifying unreported Secondary Suites __ 28

Step \#9: Identify Converted Structures and Secondary Suites not reported by MPAC ___ 28

Step \#10: Compile Results___ 28

Chapter \#5: Neighbourhood Study Areas __ 29

Overview__ 29

Study Area \#1: The Annex __ 31

Study Area \#2: The Junction___ 34

Study Area \#3: Corsa Italia - Davenport___ 37

Study Area \#4: Playter Estates - Danforth __ 40

Study Area \#5: The Beaches __ 43

Study Area \#6: Rosedale-Moore Park __ 46

Study Area \#7: Willowdale __ 49

Summary _ 52

Chapter 6: Number of Secondary Suites in Toronto___ 57

Introduction__ 57

Step \#1: Number of Converted Structures by Property Code __ 57

Step \#2: Number of Single, Semi, Row and Detached Structures with Basement Apartments

Step \#3: Number of Converted Structures Within assessment Rolls ___ 59

Step \#4: Number of Converted Structures Not Within assessment Rolls___ 59

Step \#5: Total number of Converted Structures __ 60

Step \#6: Number of Secondary Suites ___ 60

Chapter 7: Recommendations __ 61

Recommendation \#1: Improving Visual Survey Results___ 61

Recommendation \#2: Toronto Secondary Suite Survey ___ 61

Recommendation \#3: Clarify and Improve MPAC data Varialbes __ 62

Recommendation \#4: INcorporate MLS DATa __ 62

REcommendation \#5: Estimate Deconversions __ 63

REcommendation \#6: Comparisons___ 63

Chapter 8: Conclusion _ 64

Bibliography _ـ 65 


\begin{tabular}{|c|c|c|}
\hline Table \# & List of Tables & Page \# \\
\hline Table \#1 & Summary of Total MLS Listings by Location & 20 \\
\hline Table \#2 & $\begin{array}{l}\text { Secondary Suite Permits Issued from January } 1 \text { to December 31, } \\
\qquad 2012\end{array}$ & 21 \\
\hline Table \#3 & The Annex: 2012 Assessment Rolls Results & 33 \\
\hline Table \#4 & The Annex: 2012 Assessment Rolls and Visual Survey Results & 33 \\
\hline Table \#5 & The Junction: 2012 Assessment Rolls Results & 36 \\
\hline Table \#6 & The Junction: 2012 Assessment Rolls and Visual Survey Results & 36 \\
\hline Table \#7 & Corsa-Italia: 2012 Assessment Rolls Results & 39 \\
\hline Table \#8 & Corsa-Italia: 2012 Assessment Rolls and Visual Survey Results & 39 \\
\hline Table \#9 & The Danforth: 2012 Assessment Rolls Results & 42 \\
\hline Table \#10 & Danforth: 2012 Assessment Rolls and Visual Survey Results & 42 \\
\hline Table \#11 & The Beaches: 2012 Assessment Rolls Results & 45 \\
\hline Table \#12 & The Beaches: 2012 Assessment Rolls and Visual Survey Results & 45 \\
\hline Table \#13 & Rosedale: 2012 Assessment Rolls Results & 48 \\
\hline Table \#14 & Rosedale: 2012 Assessment Rolls and Visual Survey Results & 48 \\
\hline Table \#15 & Willowdale: 2012 Assessment Rolls Results & 51 \\
\hline Table \#16 & Willowdale: 2012 Assessment Rolls and Visual Survey Results & 51 \\
\hline Table \#17 & Degree of Intensification - Assessment Roll Data & 53 \\
\hline Table \#18 & $\begin{array}{c}\text { Degree of Intensification - Assessment Roll with Site and Visual } \\
\text { Survey }\end{array}$ & 53 \\
\hline Table \#19 & $\begin{array}{c}\text { Number of Converted Structures not identified in Assessment } \\
\text { Rolls }\end{array}$ & 54 \\
\hline Table \#20 & $\begin{array}{c}\text { Average Number of Secondary Suites per Converted Structure } \\
\text { identified in Assessment Rolls }\end{array}$ & 55 \\
\hline Table \#21 & Average Number of Secondary Suites for all Converted Structures & 55 \\
\hline Table \#22 & Number of Converted Structures by Property Code & 57 \\
\hline Table \#23 & $\begin{array}{c}\text { Number of Basement Apartments in Single, Semi and Row } \\
\text { Structures }\end{array}$ & 58 \\
\hline Table \#24 & Number of Converted Structures not within Assessment Rolls & 59 \\
\hline Table \#25 & Number of Converted Structures & 60 \\
\hline Table \#26 & Number of Secondary Suites & 60 \\
\hline
\end{tabular}




\begin{tabular}{|c|c|c|}
\hline Figure \# & $\begin{array}{c}\text { List of Figures } \\
\text { Figure \#1 }\end{array}$ & \begin{tabular}{c} 
Page \# \\
\hline Figure \#2
\end{tabular} \\
\hline Figure \#3 & $\begin{array}{c}\text { Private Rental Apartment Vycancy Rate, Toronto, 1970-2012 } \\
\text { Percentage Change in Average Rents vs. Inflation, Toronto, 1990- } \\
2011\end{array}$ & 5 \\
\hline Figure \#4 & $\begin{array}{c}\text { Percentage of Households Spending 30\% or More of Household } \\
\text { Income on Shelter, Toronto, 1981-2006 }\end{array}$ & 7 \\
\hline Figure \#5 & $\begin{array}{c}\text { Secondary Rental Market: Other-Primary Accessory Suites, } \\
\text { Toronto }\end{array}$ & 17 \\
\hline Figure \#6 & \begin{tabular}{c} 
Context Map \\
\hline
\end{tabular} & 29 \\
\hline
\end{tabular}




\section{Chapter \#1 Introduction}

\section{OVERVIEW}

Housing markets within many Canadian cities are becoming increasingly diverse and heterogeneous. As such, today's urban environments are now composed of numerous housing forms based on tenure and structure type, each responding to the financial resources, life stages, and preferences of homeowners and renters alike. One increasingly popular housing typology is secondary suites. Located within nearly every Canadian neighbourhood, these small rental units are an anomaly within the rental universe. Their existence often mystifies government agencies due to the fact that they are generally embedded within an underground housing market. Consequently, their role and prevalence is often ill defined.

Until recently, most government agencies were not overly concerned with estimating the number of secondary suites within their municipal jurisdictions or, for that matter, even concerned with establishing regulatory policies within their local By-laws or Official Plans. However, with the introduction of Bill 140 - Strong Communities through Affordable Housing Act, 2011, all municipal governments are now being forced to acknowledge the countless benefits associated with secondary suites and recognize their ability to address issues of housing affordability. The enabling polices outlined within Bill 140 will likely increase the presence and prominence of secondary suites within Ontario communities. In response, government agencies will need to enhance their depth of understanding and level of awareness of these increasingly important rental units.

\section{DEFINITION}

Before defining the term 'secondary suite', an important distinction within the rental housing market must first be made. That is, all residential rental units are either located within the primary or secondary rental markets. A primary rental unit is described as a 'purpose built' private or assisted rental unit. In contrast, a secondary rental unit is a private rental unit that is not 'purpose built'. According to the Starr Group, secondary rental units are defined as "nonconventional forms of rental housing not usually reported in the CMHC Annual Rental Market Survey" (2000, i). Units within this market include tenant-occupied single, semi, and row dwellings; rented condominium units; accessory apartments such as self-contained basements and flats (including both legal and illegal units); and apartments over stores. One important distinction between these two types of housing is that secondary rental units often move in and 
out of the rental market; whereas, primary rental units are relatively stable over long periods of time.

Secondary suites are generally described as a self-contained or complete housing unit with its own bathroom, kitchen, living facilities, and private entrance. These small market-rental units are typically located within a basement or attic of a single-family home. In nearly all instances, these units are installed in the surplus space of a single family home and require little to no physical expansion or alteration to the character of the house. As a result, homes with secondary units are often indistinguishable from those without (Hare and Ostler, 1990). Furthermore, the term 'secondary', as pointed out by Richard Drdla and Associates, is "intentionally used to indicate that these units are supplementary to the primary residential use of the structure" $(1988,4)$.

In addition to the term secondary suite, these rental units are also referred to as second suites; secondary apartments; basement apartments; accessory apartments; accessory suites; and mother-in-law or mother-daughter suites. However, for the purpose of this report, this form of rental housing will be consistently referred to as a secondary suite. In addition, it must also be noted that the term secondary suite does not refer to any form of shared housing in which a bathroom, kitchen or other living facilities are shared between a lodger and homeowner or between two or more lodgers or roommates. Lastly, the terms: granny flats; garden suites; laneway houses; or any other secondary rental unit not contained within the primary residential structure are not considered a secondary suite for the purpose of this report.

Lastly, it is also necessary to clarify the process through which these units are created. Residential intensification, as defined by Ministry of Housing, is achieved in four distinct ways. Examples of this process "include: various forms of sharing in existing structures; creation of new, self-contained units in existing residential buildings; conversion of non-residential space to residential use; or residential infill on unused, vacant, under-utilized or under-developed lots" (1987, forward). For the purpose of this report, a residential structure that has undergone a process of intensification resulting in the creation of one or more additional units will be referred to as a converted structure.

\section{STUDY PURPOSE}

The housing market within the City of Toronto faces a number of glaring problems of which low vacancy rates and affordability are the most prevalent and pervasive. Both renters and homeowners encounter these problems on a daily basis, a reality that negatively impacts Torontonians overall quality of life. The City of Toronto desperately needs more affordable rental 
units. The disastrous combination of a growing population coupled with a decrease in all forms of affordable rental housing will have dire consequences for all low- to medium-income households.

Secondary suites offer at least a partial solution to correct these systemic problems. These units provide both renters and homeowners an assortment of benefits including, but not limited to, affordable rents, adequate shelter in desirable neighbourhoods, and additional income to help make mortgage payments. Secondary suites are relatively easy to construct and additional units of this type can be quickly added to the existing rental housing stock. Thousands of students, single individuals, lone parents, and families rely upon these units to fill both short and long-term housing needs. However, their role within the housing market has never been fully substantiated, numerically or functionally, due to a number of inherent limitations with available information sources and data collection techniques. It is important that a "practical and reliable methodology be developed to enable the City of Toronto to measure the size of this market, develop a profile of its characteristics, and monitor conditions within this market on a regular basis" (Social Housing Strategists Inc., 2004, 7).

\section{RESEARCH QUESTIONS}

The following study seeks to shed light on the prevalence of secondary suites within the City of Toronto. This approach will require an in-depth exploration of the following research questions.

- What methodological approaches have local government agencies and academic researchers employed to determine the number of converted structures and secondary suites within urban areas?

- What are the benefits and drawbacks associated with each methodology?

- What methodologies are most appropriate within the context of Toronto?

- Through the application of the preferred methodological approach, determine how many converted structures or secondary suites exist within selected Toronto neighbourhoods?

- How many converted houses exist within Toronto's housing stock?

- How many 'reported' and 'unreported' secondary suites exist within Toronto's rental housing market? 


\section{TORONTO' RENTAL HOUSING MARKET}

Before evaluating the merits of secondary suites or reviewing the techniques to estimate their prevalence within the City of Toronto, a brief overview of the City's rental housing market is warranted. The general intent of this brief summary is to illustrate the pertinent issues facing Toronto's rental housing market. Although there is no 'silver bullet' solution to solving the City's current housing crisis, secondary suites will play an important role in addressing current trends in housing affordability and availability. The following charts and graphs were created using Canadian Mortgage and Housing Corporation's Rental Market Reports for the City of Toronto and Statistics Canada data.

\section{Households by Tenure}

The City of Toronto's rental market contains over 450,000 primary and secondary rental units. In $2006,46 \%$ of all households within the city were rental households, a figure considerably higher than the provincial average of $28 \%$ (Statistics Canada, 2010). Over the past 60 years, the number of apartment rentals has increased nearly 500\%. However, as illustrated in Figure \#1, the number of rental households within Toronto has actually decreased over the past 15 years. These decreases illustrate a number of critical changes within City's rental market. First and foremost, the decrease in the total number rental units is due primarily to the fact that very few purpose-built (public or private) rental units have been constructed during that period of time. Secondly, rental demolition or condo conversions have also contributed to a decrease in the overall supply of rental housing.

Fiqure \#1: Households by Tenure, Toronto

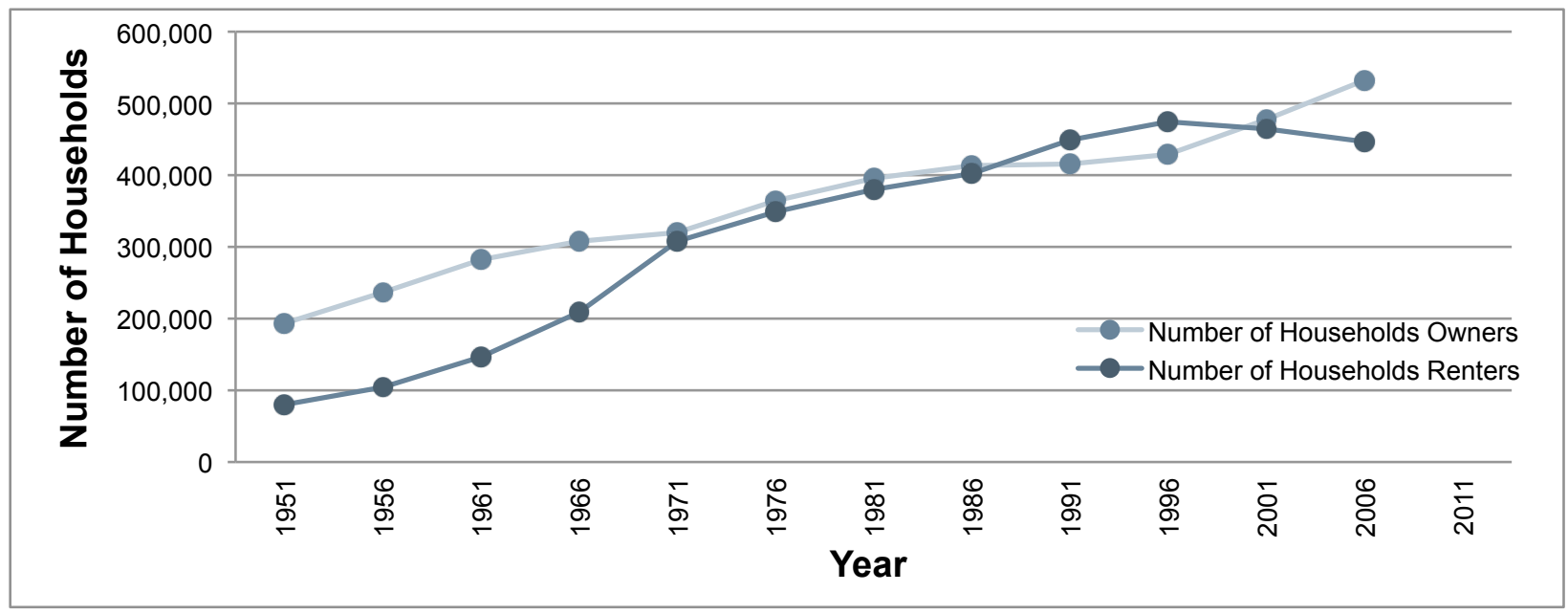

Source: City of Toronto: Profile Toronto 


\section{Vacancy Rates}

When determining the current state of a City's rental housing market, vacancy rates are frequently cited as an important indicator. Vacancy rates measure the percentage of all rental units that are vacant and available for rent at a given moment in time. Low vacancy rates "typically mean that households will have greater difficulty finding a place to rent. They may also lead to increases in rents, as more households seek to occupy a smaller pool of rental units" (Human Resources and Skill Development Canada, 2012). The vacancy rate in Toronto over the past 40 years has typically remained well below the vacancy threshold of $3 \%$ as identified within Toronto's Official Plan, an indication that the City has frequently experienced shortages in rental housing. The current vacancy rate (as of October 2011) for all rental unit types is $1.4 \%$. Again, well below acceptable thresholds.

Figure \#2: Private Rental Apartment Vacancy Rate, Toronto, 1970-2011

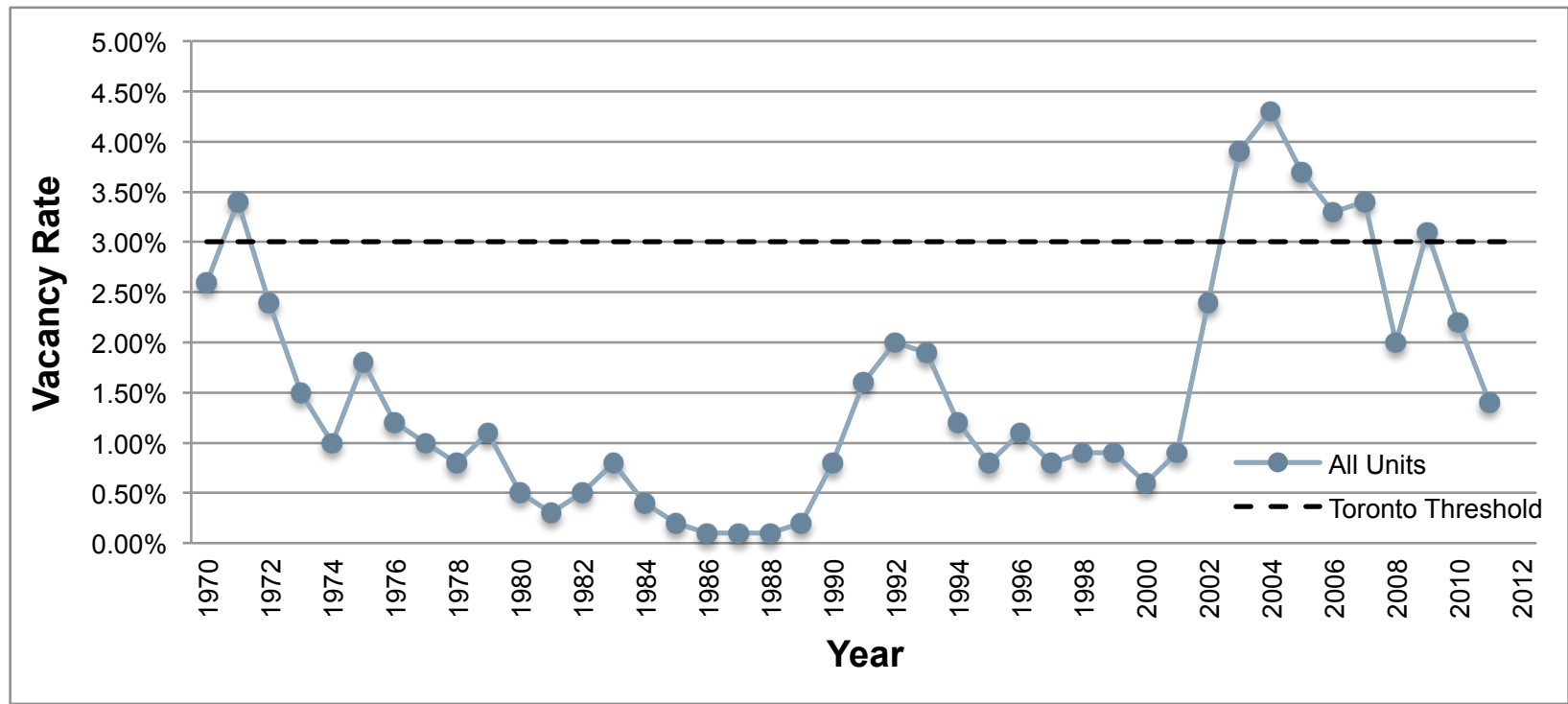

Source: City of Toronto: Profile Toronto 


\section{Average Rents}

Although yearly average rents are known to fluctuate, they are typically above $0 \%$. Meaning, average residential rents generally increase on an annual basis. In many cases, these increases are in line with the Canadian inflation rate. However, as illustrated in the graph below, average rents for bachelor apartments have risen significantly over the past three years. In 2009, the average rent for a bachelor apartment in the City of Toronto was $\$ 759$. In 2011 , this figure had risen to $\$ 822$, an increase of $8.3 \%$. In many ways this is an important figure when considering the role of secondary suites, as these units are typically small bachelor and one-bedroom units.

Figure \#3:Percentage Change in Average Rents vs. Inflation, Toronto, 1990-2011

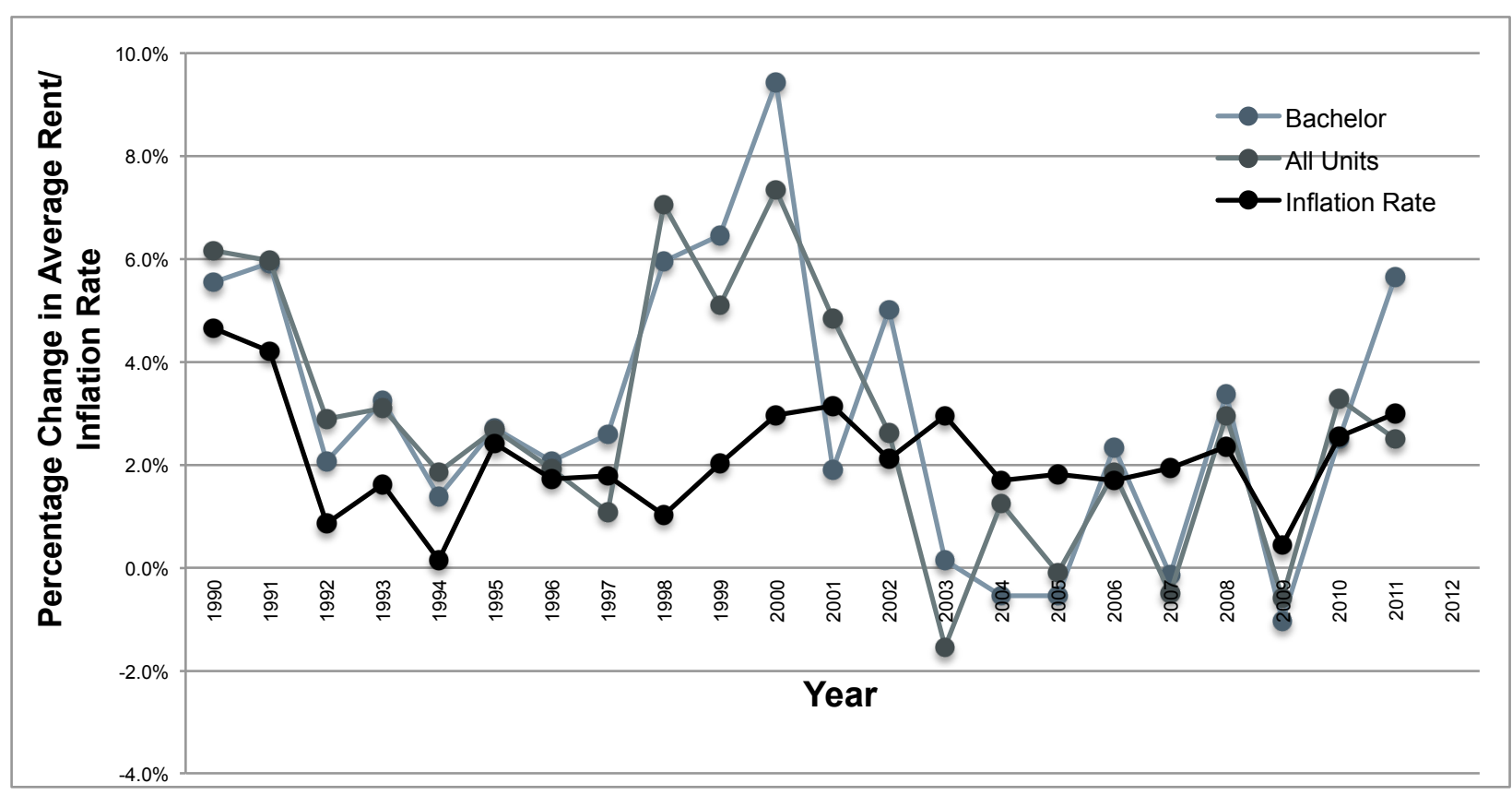

Source: City of Toronto: Profile Toronto 


\section{Household Spending}

Household spending is another important indicator to consider when evaluating housing affordability for both renters and homeowners. According to the City of Toronto's report entitled, Perspectives on Housing Affordability, households that spend more than 25 to $30 \%$ of their household income on housing are more likely to experience financial hardships (2006). Many households in the City of Toronto are presently in this financial position. The percentage of household income spent on housing in the City of Toronto has steadily increased over the past 25 years. However, this figure jumped substantially between the 2001 to 2006 census years. Currently, over $45 \%$ of renter households in Toronto spend $30 \%$ or more of their household income on rent.

Figure \#4: Percentage of Households Spending 30\% or More of Household Income on Shelter, Toronto, 1981-2006

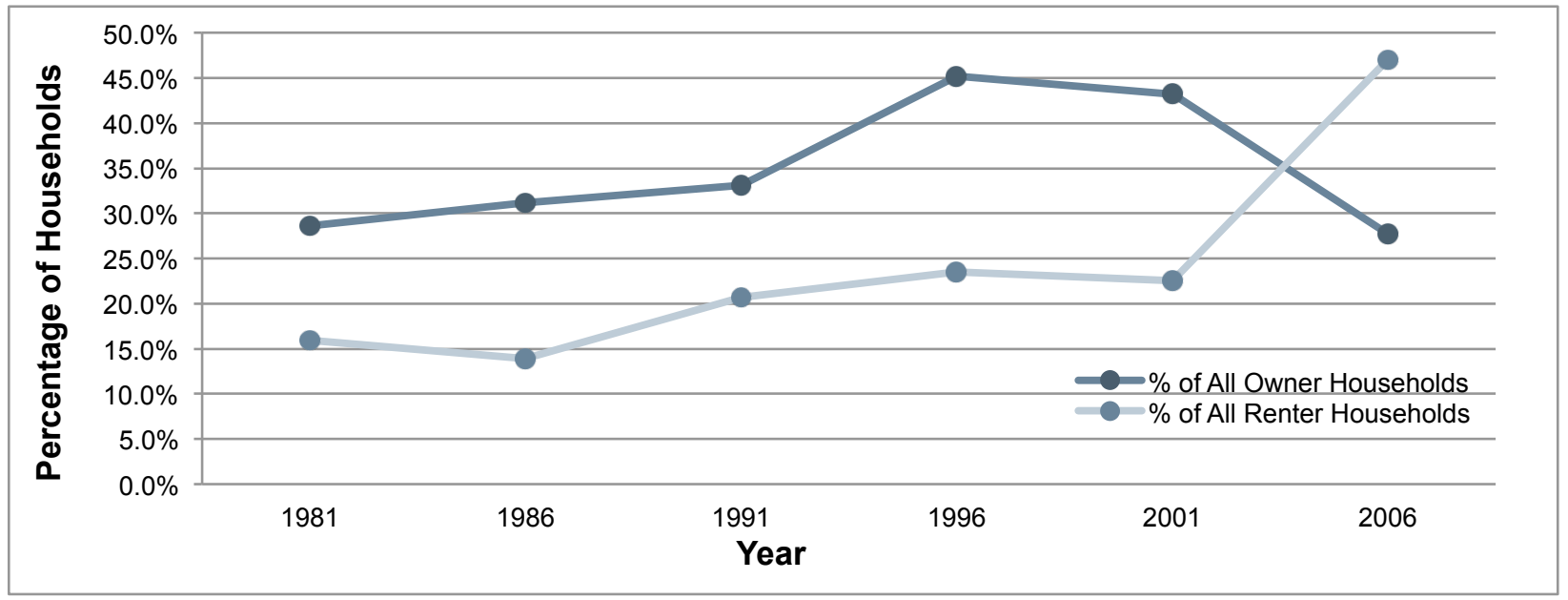

Source: City of Toronto: Profile Toronto

\section{ONTARIO LEGISLATIVE FRAMEWORK}

Housing is a matter of Provincial interest. As expressed in Section 2 of the Ontario Planning Act and illustrated through various housing related policies identified within the Provincial Policy Statement (PPS) and Growth Plan for the Greater Golden Horseshoe, each municipality must ensure the adequate provision of a full range of housing, including affordable housing (Province of Ontario, 1990). Although secondary suites were not specifically identified within these high level documents, the general intent of their policies were to ensure the entire spectrum of housing is supported and encouraged within each municipality. This includes secondary suites.

Secondary suites within the Province of Ontario exist within a relatively complex and continuously evolving legislative framework. Due to the fact that these small rental units have 
the potential to increase the number of affordable rental units within Toronto's rental universe, they have garnered considerable attention within the Legislative Assembly. Responding to the growing need for Provincial led policies related to housing and housing affordability, the Liberal government passed Bill 140 - Strong Communities Through Affordable Housing Act, 2011 on May 4, 2011. Bill 140 represents the latest approach to address affordable housing within the Province of Ontario. The purpose of this Bill is to address two key priorities:

- To provide for community based planning and delivery of housing and homelessness services with general provincial oversight and policy direction; and

- To provide flexibility for service managers and housing providers while retaining requirements with respect to housing programs that predate this Act and housing projects that are subject to those programs.

Bill 140 addresses a plethora of housing related issues including, but not limited to: the sale of non-profit and co-op housing to the private housing market; restructuring rent geared-to-income assistance and special needs housing; and secondary suites. With regard to legislation respecting secondary suites, amendments to the Planning Act include:

- Mandatory requirements that all official plans include policies authorizing the use of a second residential unit; and

- Mandatory requirements that all councils pass zoning by-laws to give effect to the second unit policies. The Minister may make regulations that authorize the use of, and prescribe requirements and standards for, second units. Such regulations will prevail over a zoning by-law passed by a council.

As of January 1, 2012 secondary suites are allowed as-of-right across the Province. The amended sections of the Planning Act require all municipalities to implement official plan policies and zoning by-law provisions to allow secondary suites in detached, semi-detached and townhouses. Under these amendments, municipal planning documents can no longer prohibit second units in houses. Existing second units and second units in new, purpose built 'convertible' houses are made a permitted use, and are legal as long as they meet Fire Code, Building Code and Planning Act standards. However, as of yet, the Province has not specified a deadline by which municipalities are required to bring their respective planning documents into conformity with Bill 140. With the introduction of Bill 140, it is apparent that the Province acknowledges the inherent benefits associated with secondary suites and recognizes that these 
units are one possible method to address issues of housing affordability for both renters and homeowners within every municipality. 


\section{Chapter \#2: Benefits, Impacts and the Role of Secondary Suites}

\section{OVERVIEW}

Currently, our depth of understanding with respect to the secondary rental market and, more specifically, secondary suites is extremely limited. This is in stark contrast to the City's primary rental market, where housing analysts have accurate statistics regarding the location, availability, and number of units within this housing sector. With the intention of providing a convincing rationale and justification for improving our general awareness of secondary suites, and the secondary rental market as a whole, the following section will provide a brief overview of their benefits and impacts and describe the role that they play within the City of Toronto's rental housing market.

\section{BENEFITS}

Secondary suites inherently provide homeowners, renters and municipalities with a number of financial, social, and environmental benefits. A simple academic search quickly reveals the breadth and depth of these positive attributes. Based on these benefits, it is no wonder the provincial government established legislation to make these small rental units as-of-right within every Ontario municipality. Their increased prevalence within the City of Toronto's rental housing market will undoubtedly help to create a more livable and affordable City. Listed below is a brief description of the positive outcomes that these units provide various stakeholders.

\section{Homeowners}

From the perspective of homeowners, the decision to create and rent out a secondary suite produces a number of tangible benefits. Although these benefits vary from homeowner to homeowner, the principal reason for creating a secondary suite is to generate additional income. This revenue is often used to help pay a mortgage or finance household maintenance costs (Social Housing Strategists, 2004). For first-time homebuyers who are looking for a suitable home for raising a future family, the rental income generated from a secondary suite help to supplement limited financial resources and carry mortgage payments (Hare and Ostler, 1987).

Murdie and Northrup, point out that the creation of a secondary suite increases the overall value of a house and enhances its position within the real estate market (1990). According to real estate agents, single-family houses with secondary suites often sell for more money than those without. 
For older homeowners, the decision to create a secondary suite may be driven by the benefits associated with having an additional person within the house. The presence of a tenant increases the perception of security, especially if the homeowner spends a significant amount of time travelling or living in a summer or winter home (Hare and Ostler, 1987). In addition, secondary suites also help senior homeowners retain independence. According to the $\mathrm{CMHC}$, prospective renters are often willing to assist elderly homeowners with regular maintenance for lower rent $(1999,5)$.

Lastly, secondary suites are often created to provide space for relatives. An adult child living in a secondary suite may provide support for an aging parent while still preserving independence for both themselves and their parents. Furthermore, Social Housing Strategists (2004) indicate that homeowners with secondary suites often house friends or family members experiencing financial hardships or relationship issues.

\section{Tenants}

As a renter, secondary suites fill a need within the rental universe that presently cannot be satisfied by the primary rental market. These units are an affordable housing option for many lower income individuals, most notably students, young professionals, immigrants, or single parents, who typically have a hard time navigating the onerous process associated with acquiring a rental unit within the purpose-built rental universe (Hare and Ostler, 1987). In addition, secondary suites often permit renters to live in desirable neighbourhoods that would otherwise be out of reach and provide a number of attractive amenities not typically available in the primary rental market. Most notably, they have access to private outdoor space, a garage or shed, and on-site laundry facilities. These benefits result in a higher quality of life for lower income renters.

\section{Municipalities}

Although not directly involved in the provision and acquisition of secondary suites, municipalities are often cited within the literature as experiencing a wide array of benefits from this form of housing. The process of 'duplexing' is undoubtedly a form of urban intensification. Like homeowners and renters, municipalities also experience a number of financial gains. Principally, secondary suites generally increase the value of the housing stock. In certain cases, this increased value generates additional tax revenue. The Ontario Ministry of Housing, argues that secondary suites potentially provide municipalities with opportunities to use existing housing 
stocks and associated infrastructure more efficiently (1987). This is particularly true in areas where the population is declining as families mature and children leave home.

According to the $\mathrm{CMHC}$, secondary suites "also provide an efficient way for municipalities to respond to the need for [affordable] housing without local government expenditures" $(1999,5)$. The rents associated with these suites are typically lower than average market rentals and, therefore, help individuals find adequate shelter without government subsidies. Secondary suites also provide municipalities with an opportunity to meet residents' housing needs in a less disruptive and obvious manner than a new rental apartment building while also maintaining neighbourhood stability.

Lastly, the CMHC points out that secondary suites are environmentally friendly as they encourage more compact communities, reduce automobile dependency, enhance public transit, result in less household energy use per person, and require fewer resources to construct (CMHC, 1999, 5).

\section{REAL AND PERCEIVED IMPACTS OF SECONDARY SUITES}

Despite their plethora of benefits, the notion of permitting secondary suites within residential neighbourhoods has "been dogged by controversy in most parts of Canada" (CMHC, 1999, 1). The presence of Nimbyism has greatly influenced municipal decision-making processes related to the provision and regulation of secondary suites. As a result, secondary suites were, prior to Bill 140, deemed illegal in most municipalities and, as a result, driven underground. The rationale provided by most homeowners in opposition to secondary suites was related to parking problems, decreased property values, loss of aesthetics, traffic noise, absentee landlords, and increased demands on infrastructure already at capacity (CMHC, 1999 and Ontario Ministry of Housing, 1987).

While conducting this literature review, the gaps between perceived and real impacts became readily apparent. The argument that homes with secondary suites do not pay their fair share for municipal services does not take into consideration household size or composition of both the homeowners living in the primary unit or the household renting the secondary suite. In many cases, adding a second unit does not mean doubling the number of people, the principal determinant of service use. Secondary suites tend to be small and are often occupied by seniors, singles, and single-parent families (CMHC, 1999). 
Concerns regarding infrastructure capacity have also not been validated. The Ontario Ministry of Environment and Energy "indicates that no specific provisions need to be made for apartments in houses in calculating water or sewage treatment capacity" (CMHC, 1999, 7). This is due primarily to the fact that "secondary suites are typically located in areas where local population is declining - often quite sharply" (CMHC, 1999, 7). US literature further substantiates these findings, arguing that secondary suites are not likely to increase the number of people in a house beyond the number for which it was likely originally designed (CMHC, 1999, 8).

Lastly, the Parking and Housing Intensification Study by the City of Toronto revealed that secondary suites, both 'reported' and 'unreported', can be successfully camouflaged in existing single family housing, producing little or no neighbourhood debate about parking problems" (Ontario Ministry of Housing, 1987, 6). Arguments regarding increased congestion resulting from secondary suites are also exaggerated. Individuals renting these units are more likely to use public transit or active modes transportation (Ontario Ministry of Housing, 1987).

Overall, arguments in opposition to secondary suites are, in many cases, drastically overstated and reflect inaccurate or incomplete information. Many established residents are not willing to accept demographic changes within their communities and neighbourhoods. They perceive secondary suites as a threat to neighbourhood character, social values, and community spirit; all of which cannot be quantified. As a result, these individuals have used parking standards and infrastructure capacity as a rationale to vilify secondary suites.

\section{CURRENT AND POTENTIAL ROLE WITHIN THE HOUSING MARKET}

As a result of the inherent benefits associated with secondary suites, these units have the ability to address a number of issues within the housing market. They provide low- to moderate-income households with adequate and affordable housing, are a viable alternative to publically funded social housing, make homeownership more affordable for first time homebuyers and empty nesters, and address the current mismatch between household size and available residential units within the housing stock.

\section{Provide Affordable rental Housing}

Secondary suites are an affordable housing option for low- and moderate-income households. They provide adequate housing for students, single parents, and young people. The landlordtenant relationship within the secondary suite housing market is often less formal than other segments. Often, the process to secure a secondary suite does not require a formal credit check, large security deposit, list of past work and rental references, or minimum age 
requirements. As a result, individuals or household who typically have difficulties navigating the primary purpose-built rental market often find it easier to access and acquire rental accommodations within the secondary suite housing market.

\section{Address shortage of affordable rental units}

As illustrated in Figures 1 through 4 provided within the previous section, housing within Toronto is getting both harder to find and harder to afford. Increasingly, households are spending large portions of available income to find adequate housing. This reality is coupled by that fact that all levels of government are operating within a more constrained fiscal environment. Consequently, the construction of new social housing developments is infrequent at best. Given the growing scarcity of federal and provincial subsidies, secondary apartments are "a promising alternative for local governments to respond to the increasing need for small living units and affordable housing, especially for the elderly population" (US Department of Housing and Urban Development, 1983, 3). Although secondary suites are by no means a catch-all solution, it is one viable method to increase the number of affordable units in the rental housing market.

\section{Provide an avenue to home ownership}

Over the past sixty years, the production of secondary suites has tended to "peak at times when prospective and existing homeowners require supplementary (rental) income... Large numbers were created during the Depression, during and after the Second World War, and during the 70's and 80 's as the baby boom generation moved first into the rental and then into the starter ownership market" (CMHC, 1990, i). It can be argued that, based on current vacancy rates, average rents, and the number of households spending more than 30 percent of their household income on shelter, the City of Toronto is about to experience a housing crisis similar to those experienced over the past century. Homeownership in the City is not in line with current incomes. Increasingly, homeownership is not a viable option for a substantial segment of Toronto households. Secondary suites help overcome these challenges. The additional income generated from these units help people get and pay a mortgage.

\section{Housing-household mismatch}

Increasingly, the housing stock within the City of Toronto is out of sync with the financial and demographic realities of households. The CMHC points out that one "precondition for the creation of an secondary suite in an owner-occupied situation is a mismatch between household size and dwelling size. This happens frequently with first-time buyers who do not yet have children, and 'empty-nesters' or seniors whose children have left home" (CMHC, 1990, i). The 
underused space in single-family homes is an untapped housing potential that can be used to create small rental units. These units have a significant role to play, especially in cities where small affordable rental units are in short supply (Ramserran, 1990, ii)

\section{ISSUES AND CONCERNS}

While secondary suites exhibit a whole host of benefits, a number of issues within this segment of the housing market are hard to ignore. Housing analysts point out that the secondary suite rental housing market is inherently elastic, meaning rental units can enter and exit the market very quickly in response to the changing economic position of the homeowner. In addition, secondary suites in many cases are illegal or not reported within municipal assessment rolls. As such, many of the units do not meet the health and safety provisions outlined by municipal housing and building authorities. Finally, tenants' rights are also a major concern as many renters of secondary suites do not have a binding contract. Consequently, their tenant rights are often compromised or outright ignored by the owner of the secondary suite. 


\section{Chapter \#3: Review of the Estimation Techniques}

\section{OVERVIEW}

In order for government agencies to adequately respond to the City of Toronto's current housing crisis, it is essential that they develop a detailed understanding of the entire rental universe. Research indicates that this is a daunting task because accurate statistical data is not available for every segment of the rental housing market. Detailed information exists for conventional purpose-built rental units within the primary rental market and for condo rental units within the secondary rental market. However, accurate information regarding the prevalence of secondary suites is extremely limited due to the fact that many units exist within an underground rental market. As a result, a precise understanding of their position within Toronto's rental universe is nearly impossible to develop even though they are an important component of the City's affordable rental housing stock.

Over the past several decades, housing analysts and researchers have employed a variety of techniques to estimate the number of secondary suites within the City of Toronto. The use of this broad range of techniques is primarily due to a number of inherent data limitations. Many of Toronto's secondary suites exist within an unregulated rental market where only the owner and tenant know of its existence. As such, most data sources only provide a partial description. In order to overcome these information gaps, researchers have often based their estimates on non-traditional housing data sources. The following section, informed by a review of both academic articles and professional planning reports, briefly summarizes a number of these techniques and data sources, and identifies their strengths and weaknesses.

\section{THE CITY OF TORONTO PROPERTY ASSESSMENT ROLLS}

According to housing analysts and researchers, any attempt to estimate the number of secondary suites within the City of Toronto's housing market typically incorporates property assessment roll data into its methodological approach. Toronto's Property assessment rolls list every property within the City and identify owner(s) and tenant(s), mailing addresses; the assessed value of each property, and structure details. Since 1997, the Municipal Property Assessment Corporation (MPAC), a not-for-profit organization, has taken full responsibility for administrating the City of Toronto's property assessment rolls. As outlined within the Ontario Assessment Act, MPAC's principal responsibilities are to establish the current value of every property and prepare municipal annual assessment rolls. This process requires the organization 
to regularly update property files and record changes to an address lot size, land use, building footprint and total square footage, and features of its primary and auxiliary buildings.

MPAC's property assessment files contain a number of variables that specifically identify the presence of a reported secondary suite and provide valuable information alluding to the existence of an unreported units. From a methodological perspective, the Toronto Property Assessment Rolls provide housing analysis with a number of advantages when estimating the prevalence of secondary suites. Firstly, MPAC can generate estimates within a relatively short period of time and on a routine basis. This inherent benefit means that researchers have the ability to monitor changes over time and identify potential trends that affect the prevalence of secondary suites. In addition, information contained within a municipality's property assessment rolls is extremely detailed, standardized, and regularly updated. As such, much of the data generated through this technique is reliable and can be provided in a timely manner.

However, in light of these advantages research also indicates that, because the presence of a secondary suite has positive impact on property values, homeowners are often reluctant to legalize or report their rental unit(s). As such, estimates relying on assessment roll data alone are likely to be significantly lower due to the number of unreported secondary suites.

\section{CMHC'S SECONDARY RENTAL MARKET REPORT (SRMS)}

On a yearly basis, the Canada Mortgage and Housing Corporation (CMHC) conducts a number of surveys to estimate the relative strengths of both the primary and secondary rental markets. The principal survey, conducted bi-annually on a sample basis, targets the primary rental market. As such only private structures with at least three rental units are identified. However, in response to this limited scope and to recognize the role that the secondary rental market plays within the rental universe, the CMHC now conducts the Secondary Rental Market (SRMS). The $\mathrm{CMHC}$ defines the "secondary rental market to include all rented dwellings not situated within structures that have at least three rental dwellings" (Gun, Carter and Osborne, 2009, 1). According to this survey, the secondary rental market is composed of the following dwelling components:

- Rented single-detached houses;

- Rented semi-detached houses;

- Rented freehold row/town homes;

- Rented duplex apartments;

- Rented secondary suites; 
- Rented condominiums; and

- One or two apartments that are part of a commercial or other type of structure.

The Secondary Rental Market Survey is conducted by telephone interviews. Information about condominium rental apartments is "obtained from the owner, manager, or building superintendent and can be supplemented by site visits if no telephone contact is made" (CMHC, 2012). Information regarding all other secondary rental units, including secondary suites, is obtained from an adult living in the household. The survey collects data on average rents and is used to determine the size of the secondary rental market.

Although the SRMS survey provides housing analysts with reliable data on the overall size of the secondary rental market, the yearly rental reports do not specifically identify secondary suites as defined within this report. Secondary suites are instead grouped together with rental units located above commercial or other uses. This category, Other-Primarily Accessory Suite, is overly broad and artificially inflates the number of estimated secondary suites, limiting the overall usefulness of the data. In addition, another major concern is that the SMRS survey does not collect data on buildings that have more than three secondary rental units. Consequently, many secondary suites are not included within the survey. Lastly, results from the SRMS survey are only available at the Census Metropolitan Level. As such, identifying the number of secondary suites within the City of Toronto is not possible.

Fiqure \#5: Secondarv Rental Market: Other-Primarv Accessorv Suites. Toronto

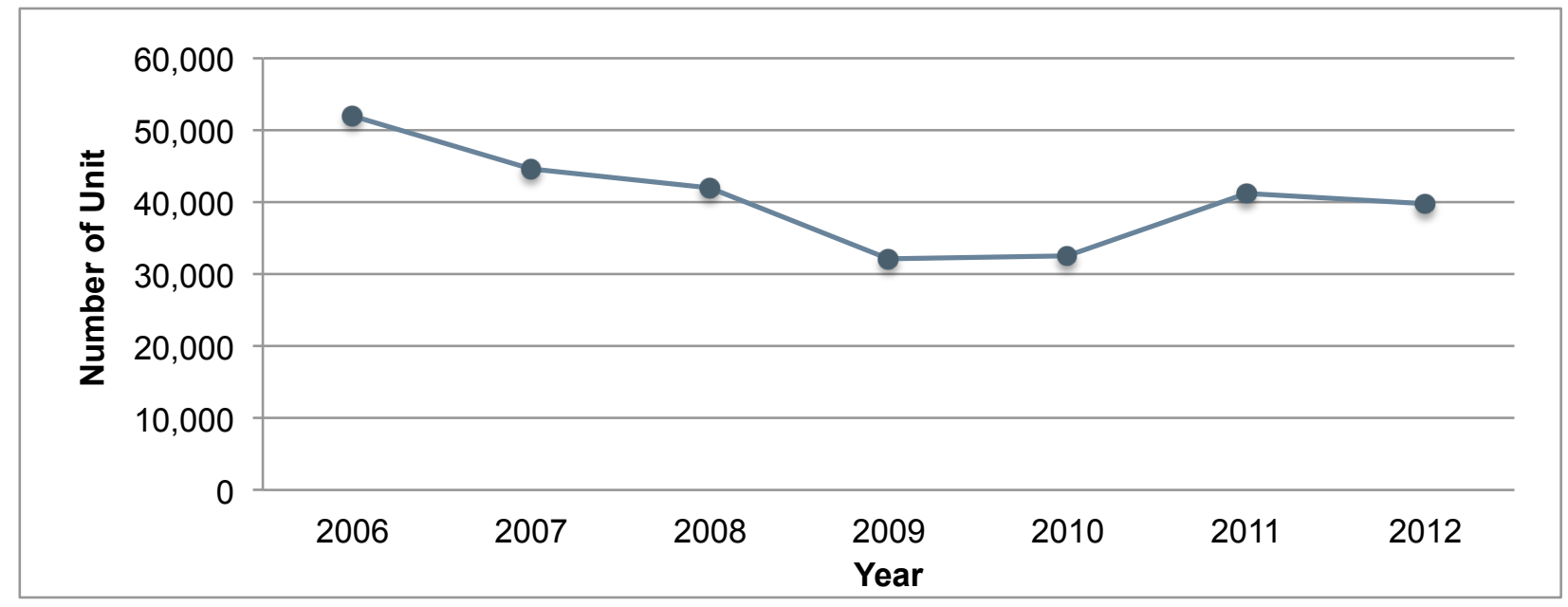

Source: CMHC Toronto Rental Market Report

As illustrated in Figure \#5, the Other-Primarily Accessory Suites category identified within CMHC's Rental Market Report is not stable. Over the past seven years, this segment of the secondary market has fluctuated on a regular basis and experienced an overall decrease of over 
11,000 rental units. Presently, there are 39,774 units located within the Toronto CMA. Although $\mathrm{CMHC}$ does not provide any ratonale, it is possible that a process of deconversion has taken place over the past decade in response to the region's overall economic prosperity.

\section{MULTIPLE LISTING SERVICES (MLS)}

In addition to federal, provincial, and municipal government agencies, the Toronto Real Estate Board (TREB) has also informally collected data on secondary suites. Although never intended to help government agencies estimate the prevalence of secondary suites within the rental housing market, the Multiple Listing Services (MLS) is an extremely valuable and accurate source of information. A MLS's database is used by "real estate brokers in real estate, representing sellers under a listing contract to widely share information about properties with other brokers who may represent potential buyers or wish to cooperate with a seller's broker in finding a buyer for the property or asset" (Ponasa Real Estate Investments, no date).

Research indicates that while homeowners are often reluctant to disclose the presence of an unreported secondary suite to municipal officials due to fear of higher property taxes or work orders to bring them up to code, they will almost always identify their presence when placing the unit for sale on the market (SHS, 2004). Within a listing add, either on-line or in print, homeowners will either explicitly indicate the presence of secondary suite or allude to their existence. For example, a recent listing in the Danforth neighbourhood provided the following description of its basement unit - professionally finished walk-up basement apartment with two bedrooms, bath, and kitchen; separate entrance; great rental income. An example of a listing that simply alludes to the existence of secondary suite will describe the basement as 'suite ready', highlight the presence of a second kitchen, or indicate that there is a separate entrance to the basement or other areas of the house.

In the past, MLS listings have been used by a number of housing analysts to estimate the number of secondary suites within many Canadian cities. According to SHS Inc. and GageBabcock and Associates, two consulting firms that used MLS listings to calculate the number of secondary suites within the City of Toronto and the City of Winnipeg, this process requires the following three steps: select a statistically significant and representative random sample of listings; determine the proportion that indicated they contain a second suite; and apply this proportion to the total stock of single detached, semi-detached, and row dwellings.

Although the MLS database is an extremely valuable source of information due to its ability to identify both reported and unreported secondary suites, it does have one major methodological 
flaw. While conducting their research, SHS recognized that houses with secondary suites might be over represented within the MLS listings. Real estate agents acknowledged this concern and suggested "units containing secondary suites tend to sell more frequently than other types of units and, therefore, may be slightly over-represented" $(2004,51)$. As such, the percentage of units with secondary suites found through a randomized search of MLS listings may not accurately reflect the percentage of units with secondary suites found within the entire housing stock.

In addition to concerns regarding over-representation, relying on MLS data to estimate the number of secondary suites may, in some instances, also lead to under-representation if the rental housing market is highly constrained, exhibits extremely low vacancy rates, and rising monthly rents. Within this context, homeowners with secondary rental units may hang on to their house with a secondary suite instead of selling. The revenue generated from this "investment property" may be too large to give up.

Table \#1: Summary of Total MLS Listings by Location, Toronto, 2004

\begin{tabular}{|l|c|c|c|c|c|}
\hline \multicolumn{1}{|c|}{ District } & $\begin{array}{c}\text { Total } \\
\text { Sample }\end{array}$ & $\begin{array}{c}\text { Reported } \\
\text { Second } \\
\text { Suites }\end{array}$ & $\begin{array}{c}\text { Proportion } \\
\text { of Listings } \\
\text { with } \\
\text { Second } \\
\text { Suites }\end{array}$ & $\begin{array}{c}\text { Total Single } \\
\text { Detached } \\
\text { Dwellings } \\
\text { (2001 } \\
\text { Census) }\end{array}$ & $\begin{array}{c}\text { Estimated } \\
\text { Number of } \\
\text { Converted } \\
\text { Structures }\end{array}$ \\
\hline Toronto & 198 & 48 & $24.2 \%$ & 117,010 & 28,366 \\
\hline Scarborough & 135 & 28 & $20.7 \%$ & 112,950 & 23,427 \\
\hline Etobicoke & 158 & 43 & $27.2 \%$ & 66,695 & 18,151 \\
\hline York, North York & 91 & 17 & $18.7 \%$ & 151,490 & 28,300 \\
\hline Amalgamated & 582 & 136 & $23.4 \%$ & 448,160 & 104,725 \\
\hline City of Toronto & \multicolumn{3}{|c|}{ Source: SHS Inc. (2004) } \\
\hline
\end{tabular}

According to SHS, in 2004 there were an estimated 104,725 single-detached, semi-detached and row structures containing secondary suites. Based on their rate of intensification and the average number of secondary suites per converted house, they determined that the total number of secondary suites within the City of Toronto was approximately 125,000.

\section{CITY OF TORONTO BUILDING PERMITS}

Since the adoption of the Secondary Suite Bylaw in 2000, the City of Toronto's Building Division has a produced a file on every legal secondary suite created within the City that required a building permit. These files provide housing analysts with extremely accurate information, describing the unit's location, construction costs, floor area, and principal structure. With the 
issuance of a building permit, legally conforming secondary suites are recorded on the City's assessment roles.

However, due to high construction costs and potential increases in property taxes, many homeowners do not obtain proper building permits. As such, most secondary suites are not recorded with the City's Building Division. Over the past 10 years, the Toronto Building Division has only issued 402 building permits for secondary suites.

Table \#2: Secondary Suite Permits Issued from January 1, 2003 to December 31, 2012

\begin{tabular}{|c|c|c|c|c|c|c|c|c|c|c|c|}
\hline District & 옹 & ষ্ণ & 농 & \&̊ & 옹 & $\stackrel{\infty}{8}$ & 옹 & 웅 & 둥 & $\frac{N}{\frac{N}{N}}$ & Total \\
\hline North & 11 & 9 & 9 & 3 & 1 & 6 & 5 & 6 & 11 & 5 & 66 \\
\hline East & 16 & 10 & 16 & 14 & 13 & 12 & 11 & 19 & 8 & 23 & 142 \\
\hline South & 15 & 6 & 7 & 19 & 18 & 6 & 3 & 1 & 7 & 10 & 92 \\
\hline West & 6 & 12 & 7 & 12 & 17 & 6 & 5 & 13 & 8 & 16 & 102 \\
\hline Total City & 48 & 37 & 39 & 48 & 49 & 30 & 24 & 39 & 34 & 54 & 402 \\
\hline
\end{tabular}

\section{NEWSPAPER ADVERTISEMENTS}

Prior to the advent of computers or the Internet, homeowners often relied upon newspaper classified ads to find prospective tenants for their secondary suite. In most cases, these ads contained information describing the type of rental unit, its location, presence of a separate entrance, number of bedrooms, and monthly rent. Researchers frequently used this available source of information to help develop a profile of secondary suites and to supplement other more traditional techniques.

\section{TELEPHONE LINES}

Historically, housing analysts counted telephone lines to estimate the number of secondary suites. At the time this was a very reliable data source because Bell Canada's database could be manipulated to identify houses with more than one telephone line and user account. However, increasingly this methodology has become less and less accurate as many secondary suite tenants have replaced landlines with mobile cell phones. 


\section{WATER METERS}

In Winnipeg, homeowners with a secondary suite are encouraged to install separate water meters in each residential unit. As such, it is possible to estimate the number of secondary suites based on the number of additional water meters located within a single, semi, or row house. This approach has the ability to help identify illegal secondary suites not captured within assessment roll data. In addition, information regarding deconversions is also accessible because most homeowners will turn off the water when the tenant vacates the rental unit. Although this technique has had some success in estimating the number of secondary suites within Winnipeg's rental housing market, its applicability within the City of Toronto is limited. Presently, homeowners with secondary suites are not encouraged to provide a separate water meter for each rental unit. As such, very few secondary suites have their own water meter.

\section{OTHER TECHNIQUES}

In addition to the techniques previously described, a number of Canadian cities have employed other methods to estimate the prevalence of secondary suites. In many cases, these techniques are site-specific and cannot be conducted within the City of Toronto. These techniques include the following:

- Voters Lists

- Hydro Hookups

- City of Toronto Enforcement Data

- Landlord's Self-Help Centre Survey

- Fire Data
- Housing Help Centres

- Internet classified ads

- Door-to-door Surveys

- Postal Walk Data

- Voters List

\section{SUMMARY}

As illustrated within this section, housing analysts have at their disposal a variety of techniques to estimate the number of secondary suites within the respective housing markets. Often, the chosen technique is based on data availability, size and scope of the study, time constraints, available financial resources, and desired accuracy. In an attempt to identify both reported and unreported secondary suites, researchers typically combine more than one estimation technique to overcome methodological limitations.

Since the last comprehensive study in 2004, many of the estimation techniques identified by SHS Consulting are no longer applicable due to societal changes and technological innovations. For example, landlines and newspapers ads are no longer able to provide reliable data to 
calculate the number of secondary suites within the City of Toronto. Cell phones have replaced landlines and newspaper ads have given way to on-line sources such as Craigslist. However, new technologies and data sources will continue to emerge. In many cases, these new data sources are likely to originate from unconventional sources made possible through technological innovations and unique partnerships between real estate agents, financial institutions, and housing researchers. 


\section{Chapter \#4: Methodological Approach}

\section{OVERVIEW}

To accomplish the general intent of this report and to answer several of the proposed research questions, it was necessary to develop an innovative methodological approach that was capable of estimating both the reported and unreported segments of the secondary suite rental market. In order to complete this task, however, it was essential to first identify the limitations and benefits associated with each estimation technique. Although the features and characteristics of a reported secondary suite are nearly identical to those of an unreported one, accurately estimating each segment requires a unique data source. For example, reported secondary suites are accurately recorded within MPAC's assessment rolls while unreported secondary suites are generally not documented at all. As result, identifying these units often requires firsthand observations. Secondly, it was essential to identify possible synergies between various estimation techniques in order to overcome the inherent limitations associated with using each one in isolation. As such, two complementary techniques - MPAC Assessment Rolls and Visual Surveys - were combined within this research report. It was anticipated that these estimation techniques would provide the most accurate estimates of the secondary suite rental market.

To estimate the number of reported converted structures and secondary suites, MPAC's assessment roll data for the City of Toronto was determined to be the most appropriate source of information due to the fact that it is generally very reliable and accessible to the public. Although this technique is typically applied at a citywide scale, the process was altered to generate estimates at the neighbourhood level. In concert with this technique, visual surveys were also used to estimate the number of unreported converted structures and secondary suites. Based on the City of Toronto's 1991 report entitled Neighbours: Pilot Project, which identified converted structures while walking along the selected streets, the visual surveys recorded observations based on a list of pre-established criteria. The observed characteristics or Items included within the pre-established list are provided in Step \#9 of this methodological approach. Through a process of visual observations, it was possible to identify unreported converted structures to further advance the results generated through assessment roll data. The following section describes each step taken within the proposed methodological approach. 


\section{STEP \#1: IDENTIFY NEIGHBOURHOOD STUDY AREAS}

Given the selected estimation techniques and the required resources required to apply the methodological approach to the entire City, it was necessary to narrow the project scope. Conducting visual surveys of every neighbourhood was simply not possible. Therefore, instead of applying each technique to the entire City, several neighbourhoods study areas were selected. The neighbourhood study areas included within this project were based on the Ministry of Municipal Affairs and Housing's report entitled Neighbours: Parking and Accessory Apartments a Metro Toronto Case Study. The following chapter provides additional information regarding the Ministry of Municipal Affairs and Housing's 1987 study on secondary suites, identifying their methodological approach for selecting these neighbourhoods. The seven selected neighbourhoods are as follows:

- The Annex (Spadina Road and Dupont Street)

- The Junction (Keele Street and Annette Street)

- Corsa Italia - Davenport (St. Clair Avenue West and Dufferin Street)

- The Danforth (Danforth Avenue and Pape Avenue)

- The Beaches (Queen Street and Victoria Park Avenue)

- Rosedale (Mount Pleasant Road at South Drive and Crescent Road)

- Willowdale (Finch Avenue and Senlac Road)

\section{STEP \#2: CREATE A PROPERTY DATABASE FOR EACH STUDY AREA}

Beyond simply identifying the neighbourhood study areas, The Ministry of Municipal Affairs and Housing also provided detailed maps delineating the boundaries of each one. Each map was recreated for the purpose of this report. These maps were subsequently used to identify all relevant addresses within each neighbourhood. These addresses were then compiled into seven Excel databases, one for each of the seven neighbourhoods.

\section{STEP \#3: IDENTIFY RELEVANT MPAC PROPERTY CODES}

The Municipal Property Assessment Corporation's Assessment Roll database contains information on every property within the City of Toronto. Each property is given a Property Code to indicate its current land use and existing structure or structures. The following Property Codes were recorded within the study area databases:

- 301: Single family detached 
- 302: More than one structure used for recreational purposes with at least one of the structures occupied permanently.

- 303: Residence with a commercial unit

- 304: Residence with a commercial/industrial use building

- 309: Freehold Townhouse/Row house - more than two units in a row with separate ownership

- 311: Semi-detached residential - two residential homes sharing a common centre wall with separate ownership

- 313: Single family detached on water - year round residence

- 314: Clergy residence

- 322: Semi-detached residence with both units under one ownership - two residential homes sharing a common wall

- 332: Residential structure with two self-contained units (typically a duplex)

- 333: Residential structure with three self-contained units

- 334: Residential structure with four self-contained units

- 335: Residential structure with five self-contained units

- 336: Residential structure with six self-contained units

- 340: Multi-residential, with 7 or more self-contained units (excluding row-housing)

- 360: Rooming or boarding house - rental by room/bedroom, tenant(s) share a kitchen, bathroom and living quarters

- 361: Bachelorette, typically a converted house with 7 or more self-contained units

These Property Code classifications were selected because they all, in theory, could contain a self-contained secondary suite.

\section{STEP \#4: IDENTIFY RELEVANT MPAC STRUCTURE CODES}

In addition to identifying property codes, it was also necessary to identify structure codes for comparison purposes. Recording a property's Structure Code is extremely valuable because it identifies the number of residential units that existed at the time of construction. Again, for the purpose of identifying converted structures and secondary suites recorded within MPAC's assessment rolls, the following structure codes were recorded:

- 301: Single family detached

- 302: Single family semi-detached 
- 303: Single family row/townhouse

- 322: Duplex - Two self-contained units

- 323: Triplex - Three self-contained units

- 324: Fourplex - Four self-contained units

- 325: Fiveplex - Five self-contained units

- 326: Sixplex - Six self-contained units

\section{STEP \#5: SELECT ADDITIONAL MPAC VARIABLES}

In addition to Property and Structure Codes, MPAC's assessment rolls also contain a number of other variables that acknowledge the presence of a reported converted structure and secondary suite. For example, within the structure details section of a property's assessment roll, MPAC provides four possible basement types - unknown; unfinished; recreation room; or basement apartment. This variable was recorded for each address.

\section{STEP \#6: RECORD ASSESSMENT DATA FOR EACH ADDRESS}

With the creation of the Excel database and a general awareness for all the pertinent assessment roll variables identified in Steps \#3 through \#5, the results of each property search was entered into the data created in Step \#2.

\section{STEP \#7: IDENTIFYING REPORTED CONVERTED STRUCTURES}

In order to identify reported converted structures, the Structure Codes identified in Step \#4 were compared to the Property codes identified in Step \#3. Comparing these two code identifies whether or not a residential structure has undergone intensification through conversion. For example, if a property's assessment roll indicates a Structure Code 301 (single family detached) and a Property Code 332 (residential structure with two self-contained units), the original Single Family Detached structure now has one additional residential unit or secondary suite. If a property assessment roll indicated a Structure Code 301 (single family detached) and a Property Code 336 (residential structure with five self-contained units), the original Single Family Detached structure now has five additional units or secondary suites. Lastly, if a property assessment roll has a basement apartment, it too has undergone intensification through conversion regardless of Structure or Property Code. 


\section{STEP \#8: IDENTIFYING UNREPORTED SECONDARY SUITES}

Like the previous step, comparing the results of Step \#3 and Step \#4 also identified the number reported secondary suites. However, one additional component must be identified. If, for example, a property assessment roll indicated a Structure Code 301 (single family detached), a Property Code 301 (single family detached), and a basement apartment the original family structure now has one additional unit.

\section{STEP \#9: IDENTIFY CONVERTED STRUCTURES AND SECONDARY SUITES NOT REPORTED BY MPAC}

Using the original database developed to record assessment roll data, printable survey tables were created for each study area. These survey tables were to record all appropriate information observed during each visual survey. The following building characteristics were examined during the site visits:

- Garbage and recycling bins

- Doorbells and mailboxes

- Hydro meters

- Barbeques on the front porch

- Basement or side entrances

- Satellite dishes

- Balconies

- Fire escapes

- Window treatments

Although relying on these characteristics alone to identify the presence of an illegal secondary suite is relatively subjective, when a house exhibits more than two or three of these identified features it is highly probable that it contains a secondary suite. Each neighbourhood site visit took approximately two to three hours to complete and was conducted on garbage day whenever possible to record the number of bins for each house. In many cases, these bins contained numbers or letters indicating which residential unit they belonged. Observations such as these were recorded within the survey tables.

\section{STEP \#10: COMPILE RESULTS}

Once all the surveys were completed, all observations were entered into the databases created during Step \#2. The results of this two-stage process are illustrated within the following section. 


\section{Chapter \#5: Neighbourhood Study Areas}

\section{OVERVIEW}

Twenty-five years ago, the Ministry of Municipal Affairs and Housing conducted a study on secondary suites in the City of Toronto. This report, entitled Neighbours: Parking and Accessory Apartments a Metro Toronto Case Study, applied a number of estimation techniques including detailed door-to-door interviews and parking utilization surveys. Although the methodological approach differs greatly to those employed within this report, the study areas selected by the Ministry of Municipal Affairs and Housing were chosen after a thorough review of neighbourhoods across the City of Toronto. According to the initial report, the steering committee "established a set of factors to be used in the selection of the seven study areas. From the outset, it was determined that each study area should be unique in terms of its physical and socio-economic characteristics" (Ministry of Municipal Affairs and Housing, 1987, 43). As such, the selection process considered a number of unique characteristics, building age, built density, proximity to downtown, and access to transit. The seven neighbourhoods are as follows:

- The Annex (Spadina Road and Dupont Street)

- The Junction (Keele Street and Annette Street)

- Corsa Italia - Davenport (St. Clair Avenue West and Dufferin Street)

- The Danforth (Danforth Avenue and Pape Avenue)

- The Beaches (Queen Street and Victoria Park Avenue)

- Rosedale (Mount Pleasant Road at South Drive and Crescent Road)

- Willowdale (Finch Avenue and Senlac Road)

Due to the original study's comprehensive selection process, it made practical sense to use the same seven neighbourhoods. However, it must be noted that several of the original study area names have been altered to better reflect each neighbourhood. For example, the Junction was referred to as Keele/Dundas in the original report. The following map illustrates the distribution of the neighbourhood study areas throughout the city.

The following neighbourhood study areas are broken down into the several elements: a brief overview of the area and its current built form, a map delineating the selected residential area; a brief socio-demographic profile; and table illustrating the results from the applied estimation techniques. Within each table the following structure codes correlate to the given structure code descriptions:

- $\quad$ Single detached - 301 
- $\quad$ Semi-detached - 302

- Duplex -322

- Townhouse -303

- $\quad$ Other - 323, 324, 325 and 326.

Figure \#6: Context Map

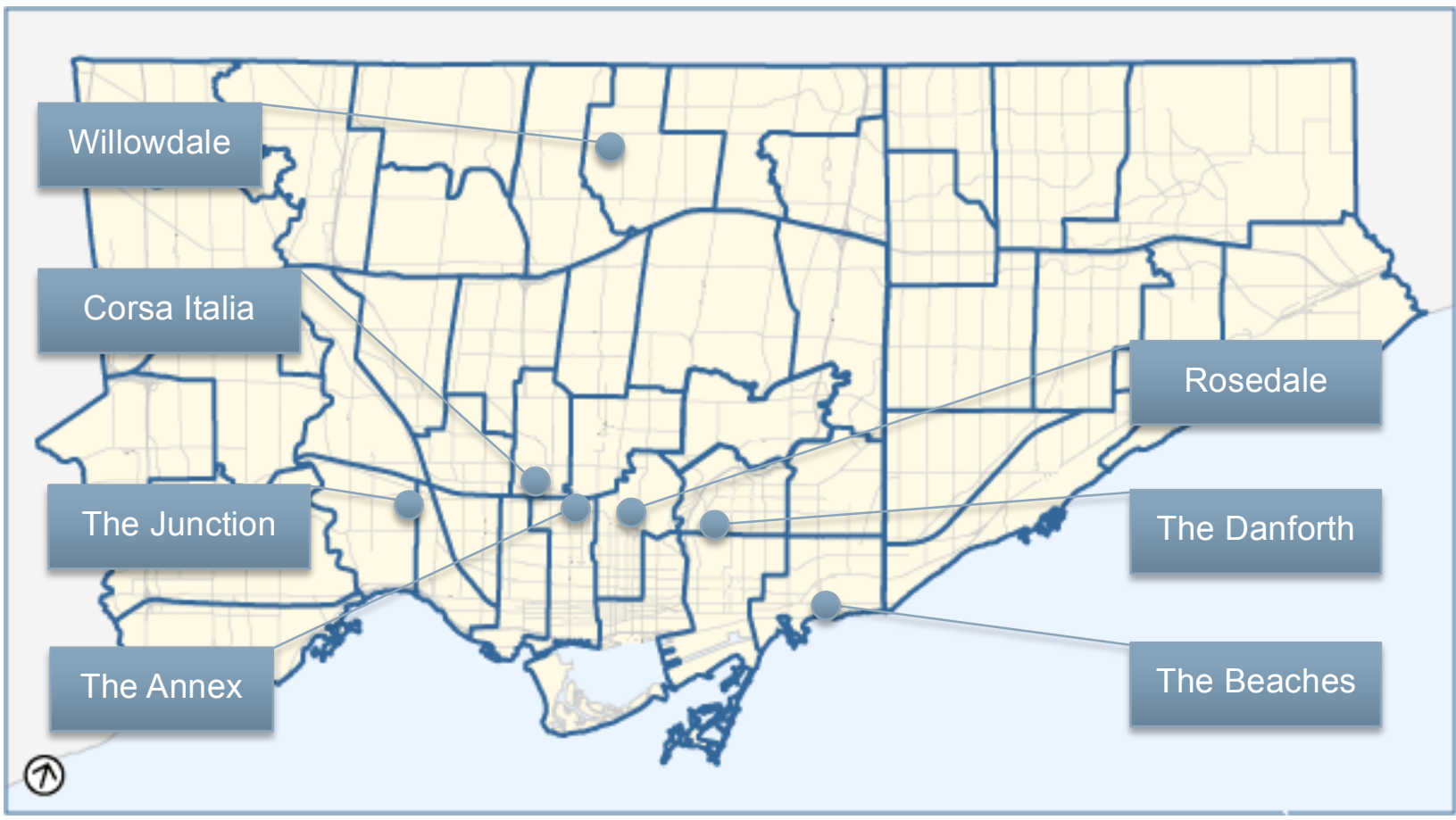

Source: City of Toronto

Unfortunately, the results generated from the original study cannot be used as a baseline for comparison due to methodological differences. The estimation techniques employed within this project - assessment roll data and visual surveys - are very different from those used by the Ministry of Municipal Affairs and Housing within their Metro Toronto Case Study. Furthermore, due to the small sample size of the initial 1987 study, accurate comparisons are not possible. 


\section{STUDY AREA \#1: THE ANNEX}

The Annex neighbourhood is one of Toronto's most prestigious and desirable residential neighbourhoods. Located in the very heart of the city, this neighbourhood is generally bounded by Dupont Street to the North, Bloor Street to the South, Avenue Road to the East and Bathurst Street to the West. As illustrated in the map provided below, the Annex Study Area is composed of four residential blocks, located immediately south of Dupont Street and one half-block to the west of Spadina Avenue.

Originally subdivided in during the 1870's and 1880's, the Annex witnessed two waves of residential development, the first during the late 1800's and the most recent between 1910-1930. The existing housing stock is characterized by large, single-detached and semi-detached houses on relatively large lots and reflects the wealth of the Annex's original residents. However, over the past several decades, the residential population has become extremely heterogeneous, providing housing for wealthy business people, students and prominent artists.

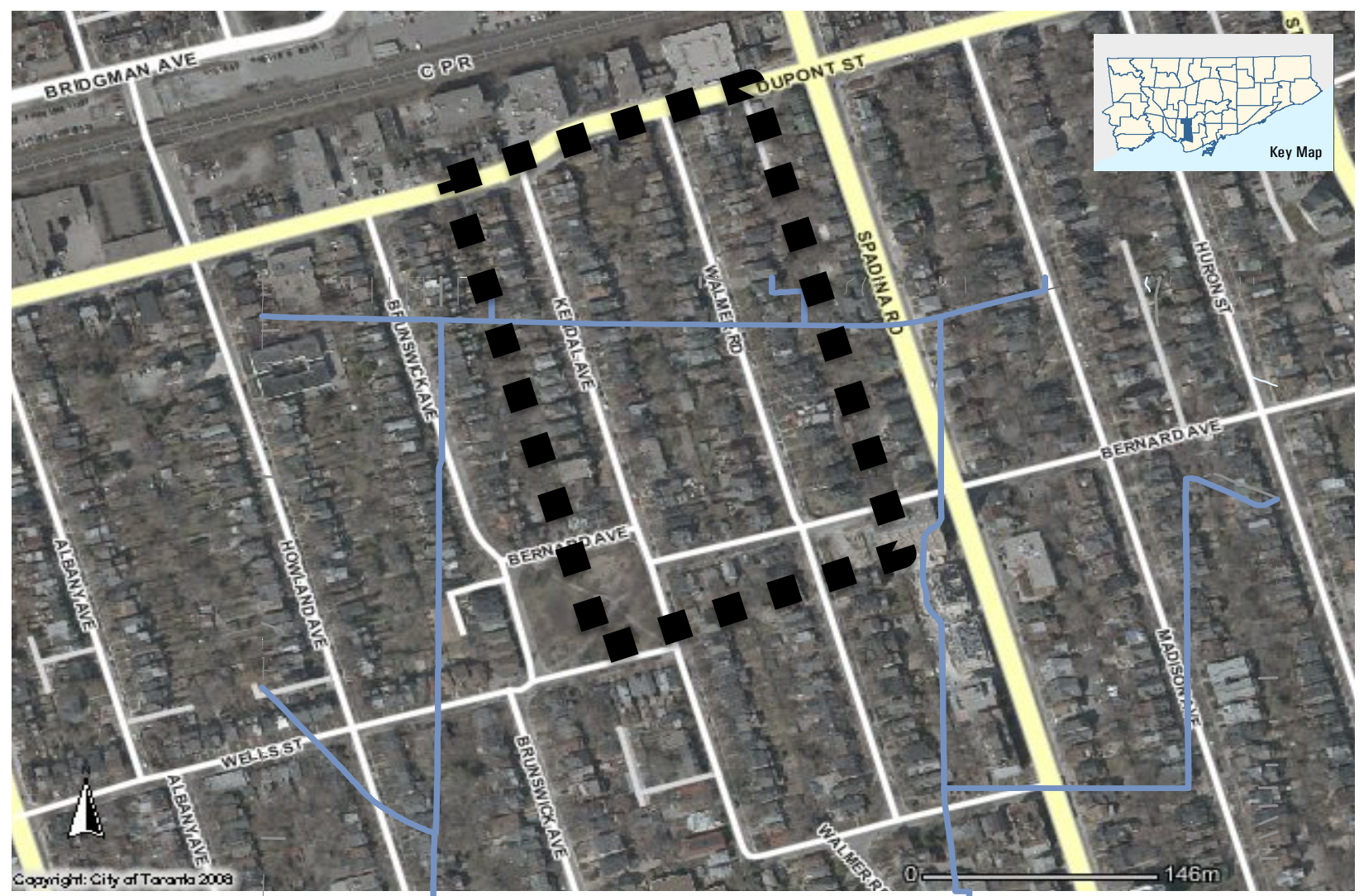



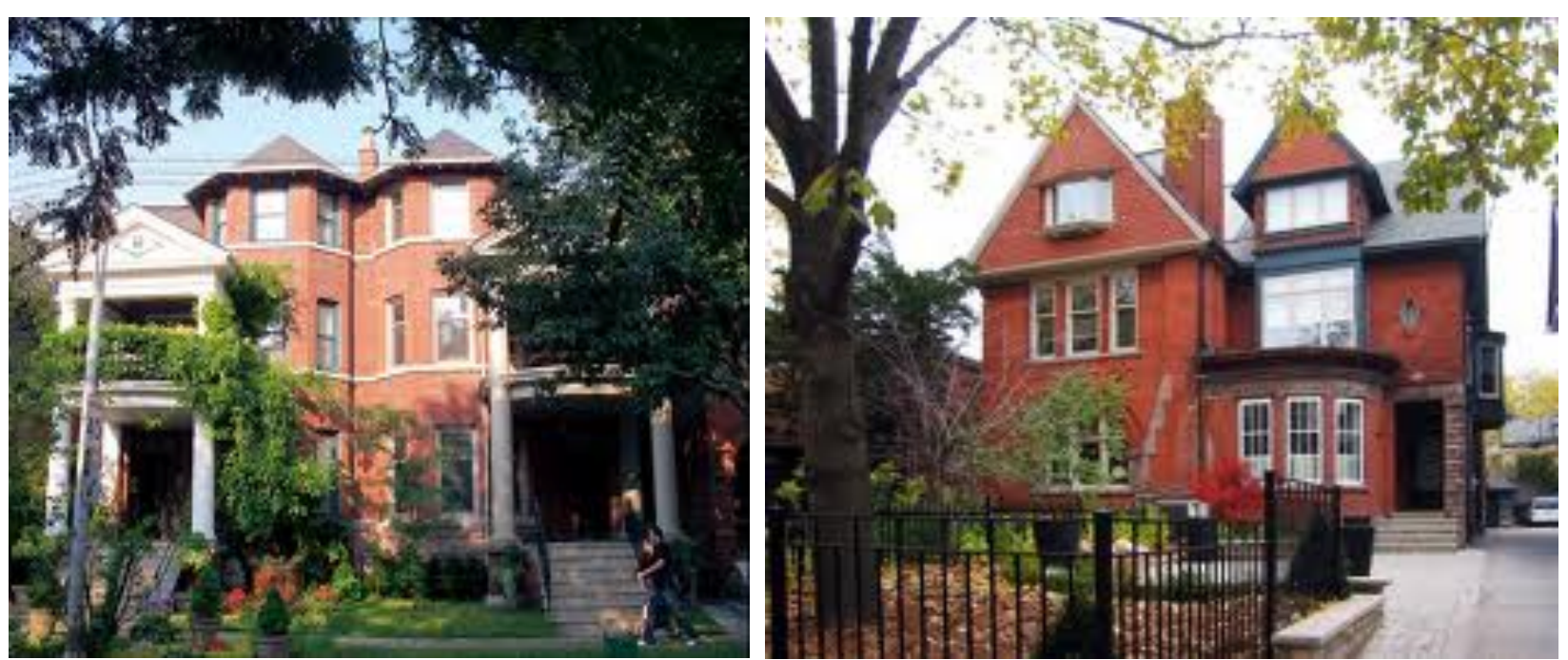

According to the 2006 Canadian Census, the Annex neighbourhood currently exhibits the following socio-demographic statistics:

- Percentage of Renter Households: $64 \%$

- Average Household income: $\$ 53,873$

- Average rent: $\$ 1,134$

- Residents spending $30 \%$ or more of their yearly income on rent: $\mathbf{3 6 \%}$

- Average household value: $\$ 641,292$

According to the City of Toronto's Neighbour's Report entitled, Parking and Accessory Apartments: A Metro Toronto Case Study, the Annex was selected as being representative of an older inner city neighbourhood with excellent transit accessibility" $(1987,43)$. As indicated by the statistics previously identified, this neighbourhood has attracted a great number of students due to its proximity to the University of Toronto, local amenities along Bloor Street, and high order transit with the Bloor Subway line.

According to the 2012 Assessment Rolls, the Annex has the highest degree of intensification. Currently, $46 \%$ of all single detached and semi-detached houses in the area contain at least one secondary suite. These figures are under-estimated as many houses contain illegal rental units. When the assessment roll figures were added to those generated during the visual survey, the degree of intensification rose to almost $70 \%$.

Tables 3 and 4 provided below identify the number of secondary suites and summarize the degree of intensification within each housing type. 
Table \#3: The Annex - 2012 Assessment Rolls

\begin{tabular}{|l|c|c|c|c|}
\hline Structure Code & $\begin{array}{c}\text { No. of } \\
\text { Structures }\end{array}$ & $\begin{array}{c}\text { No. of Structures } \\
\text { with Secondary } \\
\text { Suites }\end{array}$ & $\begin{array}{c}\text { Degree of } \\
\text { Intensification }\end{array}$ & $\begin{array}{c}\text { Total Number of } \\
\text { Secondary } \\
\text { Suites }\end{array}$ \\
\hline Single Detached & 79 & 36 & $46 \%$ & 90 \\
\hline Semi-Detached & 108 & 50 & $46 \%$ & 96 \\
\hline Duplex & - & - & - & - \\
\hline Townhouse & 2 & 2 & $100 \%$ & 5 \\
\hline Other & 6 & 1 & $17 \%$ & 1 \\
\hline Total & 195 & 89 & $46 \%$ & 192 \\
\hline
\end{tabular}

Table \#4: The Annex - 2012 Assessment Rolls and Visual Survey

\begin{tabular}{|l|c|c|c|c|}
\hline Structure Code & $\begin{array}{c}\text { No. of } \\
\text { Structures }\end{array}$ & $\begin{array}{c}\text { No. of Structures } \\
\text { with Secondary } \\
\text { Suites }\end{array}$ & $\begin{array}{c}\text { Degree of } \\
\text { Intensification }\end{array}$ & $\begin{array}{c}\text { Total Number of } \\
\text { Secondary } \\
\text { Suites }\end{array}$ \\
\hline Single Detached & 79 & 53 & $67 \%$ & 120 \\
\hline Semi-Detached & 108 & 74 & $69 \%$ & 146 \\
\hline Duplex & - & - & - & - \\
\hline Townhouse & 2 & 2 & $100 \%$ & 6 \\
\hline Other & 6 & 3 & $60 \%$ & 3 \\
\hline Total & 195 & 132 & & 275 \\
\hline
\end{tabular}




\section{STUDY AREA \#2: THE JUNCTION}

The Junction is one of Toronto's most complex residential neighbourhoods. Located in West Toronto between a network of railway lines this neighbourhood is generally bounded by Glen Scarlett Road to the North, Humberside Avenue to the South, the CNR/CPR tracks to the East and Runnymede Road to the West. As illustrated in the map provided below, the Junction Study Area is composed of three residential blocks, located just South of Annette Street and one halfblock to the west of Keele Street.

The Junction neighbourhood, formally referred to as the Village of West Toronto Junction, was founded in 1884. After a series of mergers with other villages, the Town of West Toronto Junction was amalgamated into the City of Toronto in 1909. As a result of its industrial past, the neighbourhood is characterized by small to medium sized single detached and semi-detached brick houses located on medium sized lots.

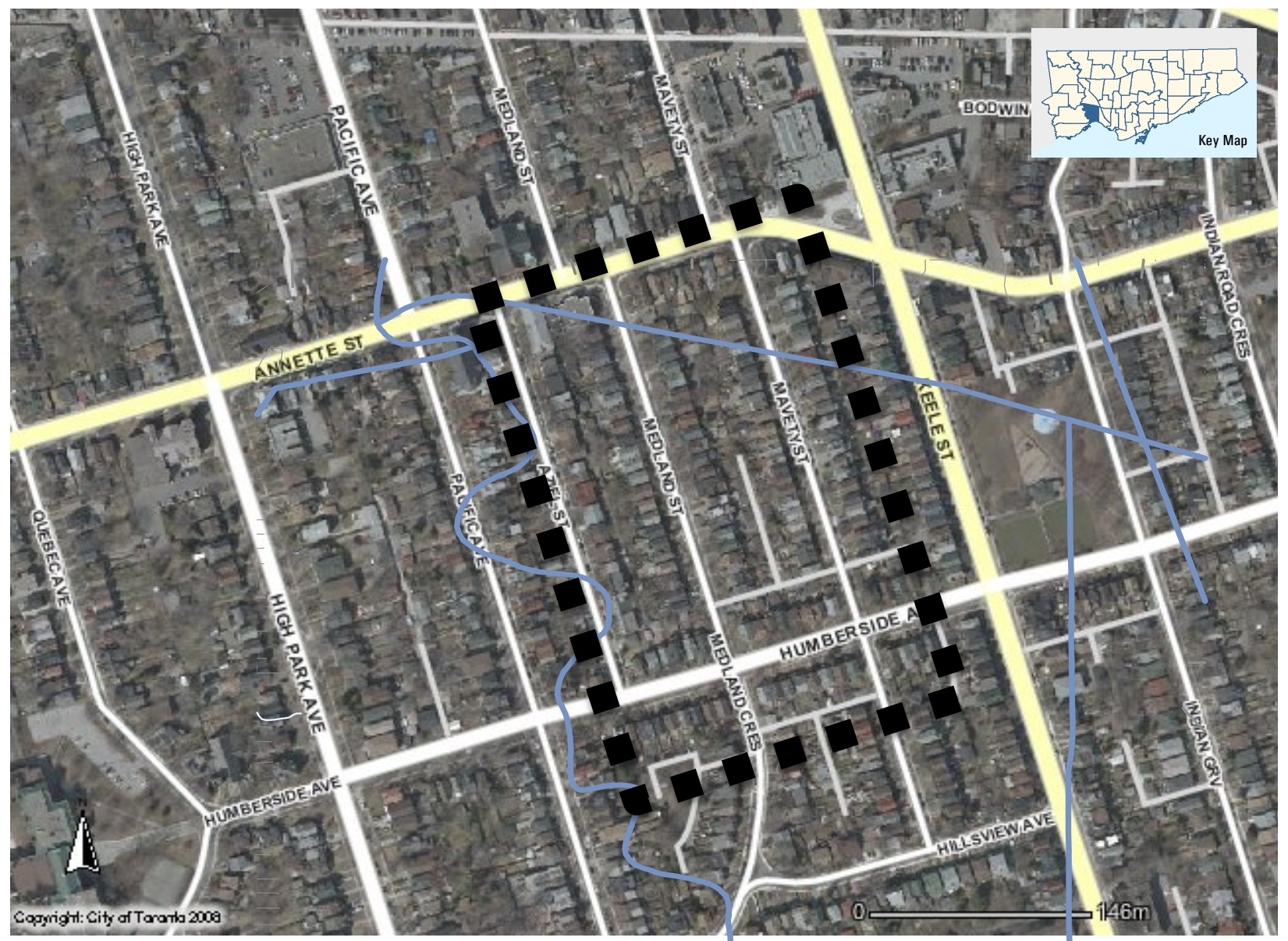



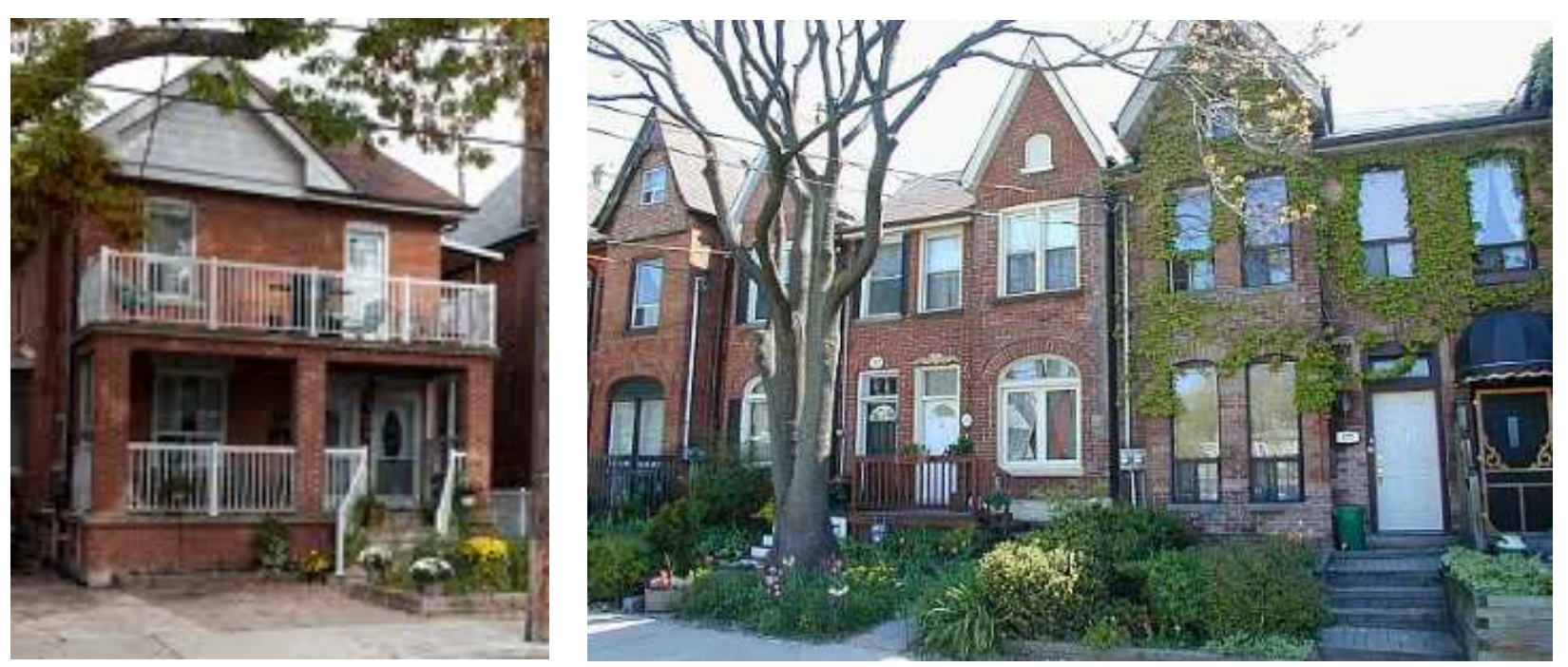

According to the 2006 Canadian Census, the Junction neighbourhood currently exhibits the following socio-demographic statistics:

- Percentage of Renter Households: $\mathbf{4 5 \%}$

- Average Private Household income: $\$ 67,303$

- Average rent: $\$ \mathbf{8 7 5}$

- Renters spending $30 \%$ or more of their yearly income on rent: $\mathbf{3 5 \%}$

- Average household value: $\$ 366,468$

According to the City of Toronto's Neighbour's Report entitled, Parking and Accessory Apartments: A Metro Toronto Case Study, the Junction was selected "as an example of a neighbourhood that is located between the core area and suburban areas, but, with good public transit accessibility" (1987). Currently, $32 \%$ of all buildings within the project area contain a secondary suite. After conducting the physical survey, this figure was increased to $47 \%$. Table \#5 and Table \#6 identify the number of secondary suites and summarize the degree of intensification within each housing type. 
Table \#5: The Junction - 2012 Assessment Rolls

\begin{tabular}{|l|}
\hline Structure Code \\
\hline Single Detached \\
\hline Semi-Detached \\
\hline Duplex \\
\hline Townhouse \\
\hline Other \\
\hline Total
\end{tabular}

\begin{tabular}{|c|c|c|c|}
\hline $\begin{array}{c}\text { No. of } \\
\text { Structures }\end{array}$ & $\begin{array}{c}\text { No. of Structures } \\
\text { with Secondary } \\
\text { Sultes }\end{array}$ & $\begin{array}{c}\text { Degree of } \\
\text { Intensification }\end{array}$ & $\begin{array}{c}\text { Total Number of } \\
\text { Secondary Suites }\end{array}$ \\
\hline 129 & 49 & $38 \%$ & 69 \\
\hline 77 & 13 & $17 \%$ & 15 \\
\hline 14 & 8 & $57 \%$ & 10 \\
\hline 4 & 3 & $75 \%$ & 5 \\
\hline 15 & 4 & $27 \%$ & 5 \\
\hline 239 & 77 & $32 \%$ & 104 \\
\hline
\end{tabular}

Table \#6: The Junction - 2012 Assessment Rolls and Visual Survey

\begin{tabular}{|l|c|c|c|c|}
\hline Structure Code & $\begin{array}{c}\text { No. of } \\
\text { Structures }\end{array}$ & $\begin{array}{c}\text { No. of Structures } \\
\text { with Secondary } \\
\text { Suites }\end{array}$ & $\begin{array}{c}\text { Degree of } \\
\text { Intensification }\end{array}$ & $\begin{array}{c}\text { Total Number of } \\
\text { Secondary Suites }\end{array}$ \\
\hline Single Detached & 129 & 71 & $55 \%$ & 94 \\
\hline Semi-Detached & 77 & 20 & $26 \%$ & 25 \\
\hline Duplex & 14 & 10 & $71 \%$ & 12 \\
\hline Townhouse & 4 & 4 & $100 \%$ & 6 \\
\hline Other & 15 & 8 & $53 \%$ & 11 \\
\hline Total & 239 & 113 & $47 \%$ & 148 \\
\hline
\end{tabular}




\section{STUDY AREA \#3: CORSA ITALIA - DAVENPORT}

The Corsa Italia-Davenport Study Area is located between downtown Toronto and other suburban areas and is delineated by Morrison Avenue to the North, Davenport Avenue to the South, Oakwood Avenue to the East, and the CNR tracks to the West. As illustrated in the map provided below, the Corsa Italia-Davenport Study Area is comprised of four small residential blocks, located one block South of St. Clair Avenue West and approximately halfway between Oakwood Avenue to the East and Dufferin Street to the West.

Originally settled by British immigrants in 1906, this area was annexed by the City of Toronto in 1910. The area is characterized by large single detached homes on medium-sized lots. The housing stock was generally built between World War I and World War II. Since that time, the area has experienced a number changes in its ethnic composition. Italian immigrants have gradually replaced the original British residents.

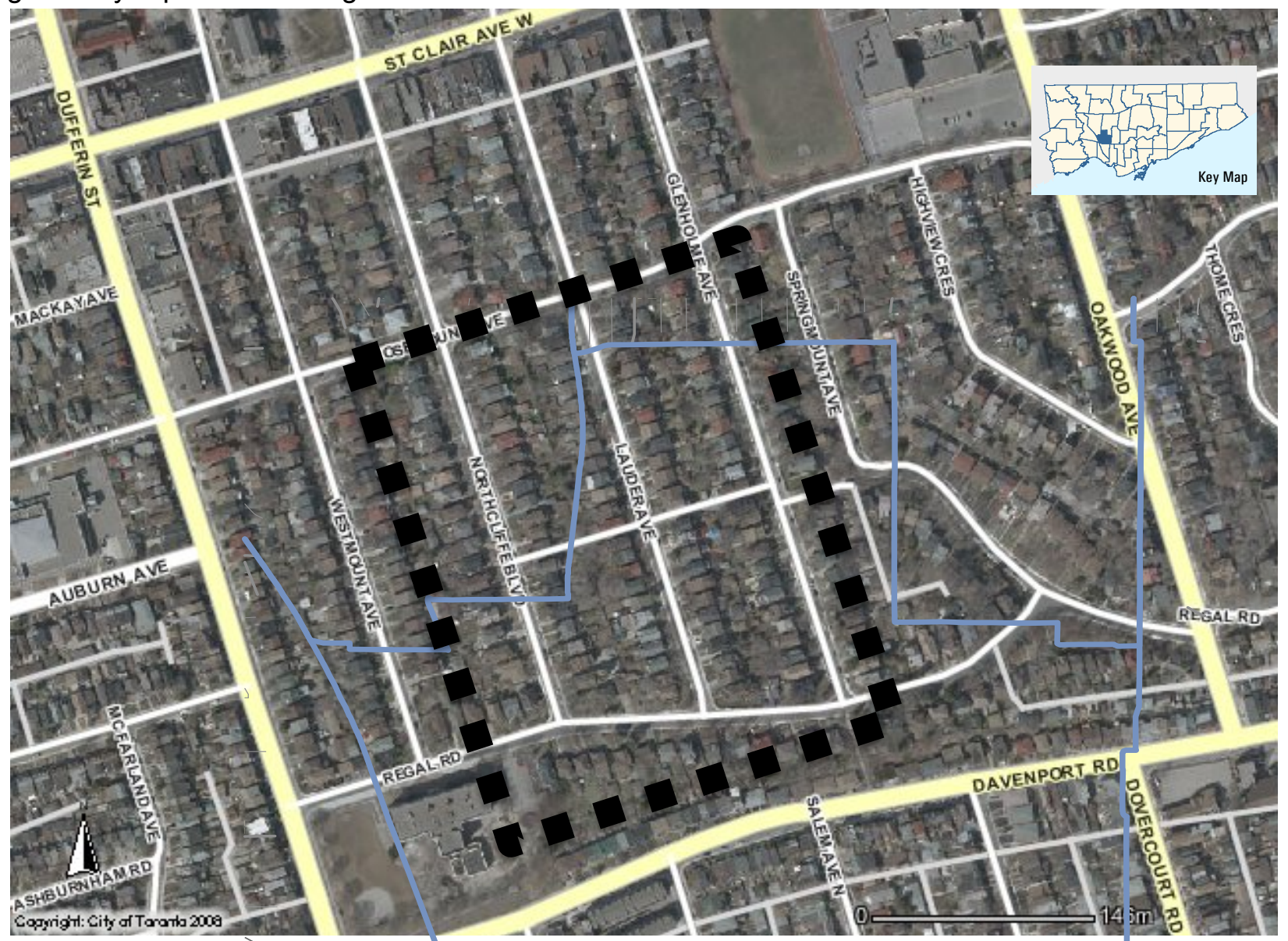



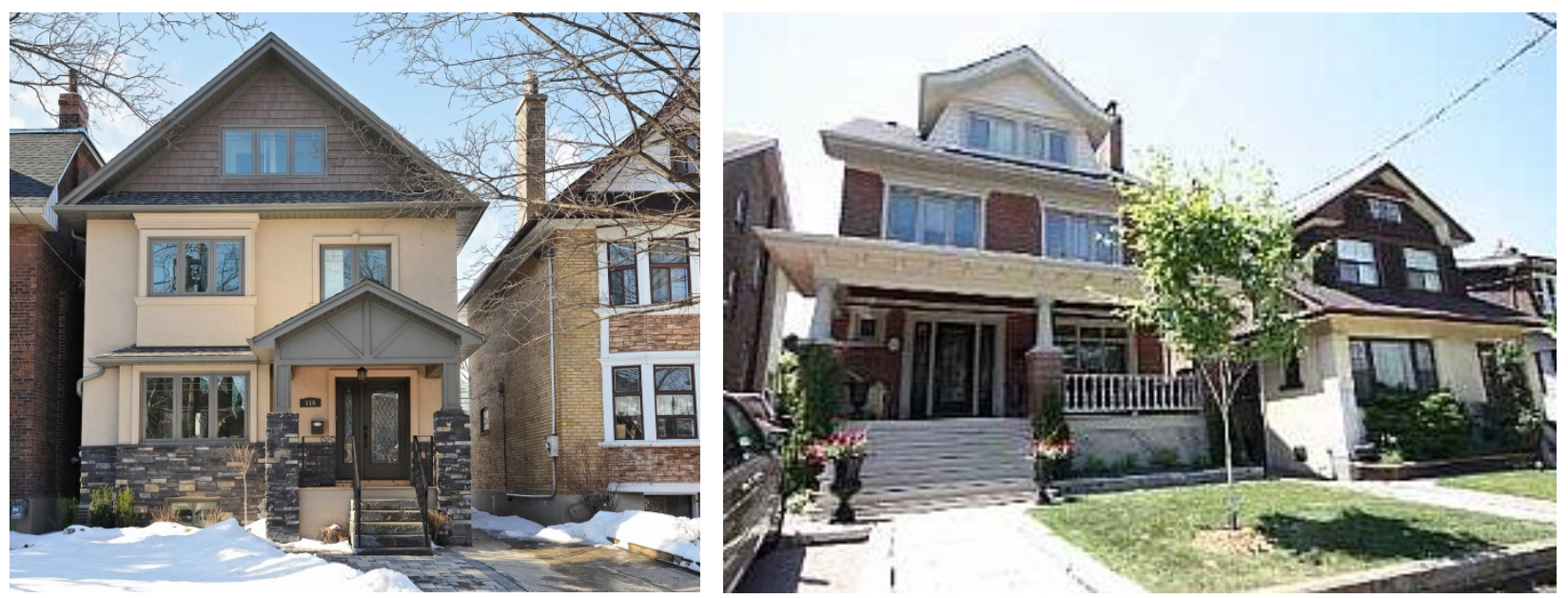

According to the 2006 Canadian Census, the Corsa Italia - Davenport neighbourhood currently exhibits the following socio-demographic statistics:

- Percentage of Renter Households: $\mathbf{3 2 \%}$

- Average Private Household income: $\$ 61,409$

- Average rent: $\$ 872$

- Renters spending $30 \%$ or more of their yearly income on rent: $\mathbf{3 2} \%$

- Average household value: $\$ 362,465$

The Corsa Italia-Davenport Study Area was selected as a neighbourhood that has experienced gentrification. Many of the single detached houses show extensive renovations. Due to its affordability and access to public transportation, the area has experienced significant intensification. In 2012, the assessment rolls indicated that $29 \%$ of these structures contained a secondary suite. When these figures were added to the results of the physical survey, $44 \%$ of all houses contained a secondary suite. Many of which contained more than one. Table \#7 and Table \#8 provided below identify the number of secondary suites and summarize the degree of intensification within each housing type. 
- Table \#7: Corsa-Italia - 2012 Assessment Rolls

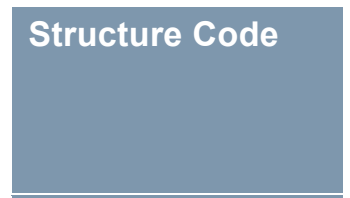

\begin{tabular}{c|c|} 
No. of & No. of Structures \\
Structures & with Secondary \\
Suites
\end{tabular}

\section{Single Detached \\ Semi-Detached}

\section{Duplex}

\section{Townhouse}

\section{Other}

Total
154

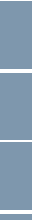

3

\begin{tabular}{|c|}
\hline 3 \\
\hline- \\
\hline 1 \\
\hline 157 \\
\hline
\end{tabular}

41

41

$-$

3

$-$

1
45

Degree of

Intensification

Total Number of
Secondary Suites

\begin{tabular}{|c|c|}
\hline $27 \%$ & 69 \\
\hline- & - \\
\hline $100 \%$ & 3 \\
\hline- & - \\
\hline $100 \%$ & 3 \\
\hline $29 \%$ & 75 \\
\hline
\end{tabular}

\section{Table \#8: Corsa-Italia - 2012 Assessment Rolls and Visual Survey}

\begin{tabular}{|l|c|c|c|c|}
\hline Structure Code & $\begin{array}{c}\text { No. of } \\
\text { Structures }\end{array}$ & $\begin{array}{c}\text { No. of Structures } \\
\text { with Secondary } \\
\text { Suites }\end{array}$ & $\begin{array}{c}\text { Degree of } \\
\text { Intensification }\end{array}$ & $\begin{array}{c}\text { Total Number of } \\
\text { Secondary Suites }\end{array}$ \\
\hline Single Detached & 154 & 65 & $42 \%$ & 100 \\
\hline Semi-Detached & - & - & - & - \\
\hline Duplex & 3 & 3 & $100 \%$ & - \\
\hline Townhouse & - & - & - & 3 \\
\hline \hline Other & 1 & 1 & $100 \%$ & 106 \\
\hline Total & 157 & 69 & $44 \%$ & \\
\hline
\end{tabular}


STUDY AREA \#4: PLAYTER ESTATES - DANFORTH

The Playter Estates - Danforth Study Area is located in Toronto's East end. Known for its large Greek population the area is delineated by Fulton Road to the North, Danforth Avenue to the South, Pape Avenue to the East, and the Don River Valley to the West. As illustrated in the map provided below, the Danforth Study Area is comprised of six residential blocks, located one half block North of Danforth Avenue and West of Pape Avenue.

Once farmland, the Playter Estates - Danforth neighbourhood was originally subdivided in 1912 (Toronto Neighbourhood Guide, 2013). Over the past 100 years, this neighbourhood has gradually developed into an exclusive enclave with many beautiful single detached and semidetached houses. The overall density of the area is relatively high when compared to other study areas, as many of the houses are located on lots that are both narrow and shallow.

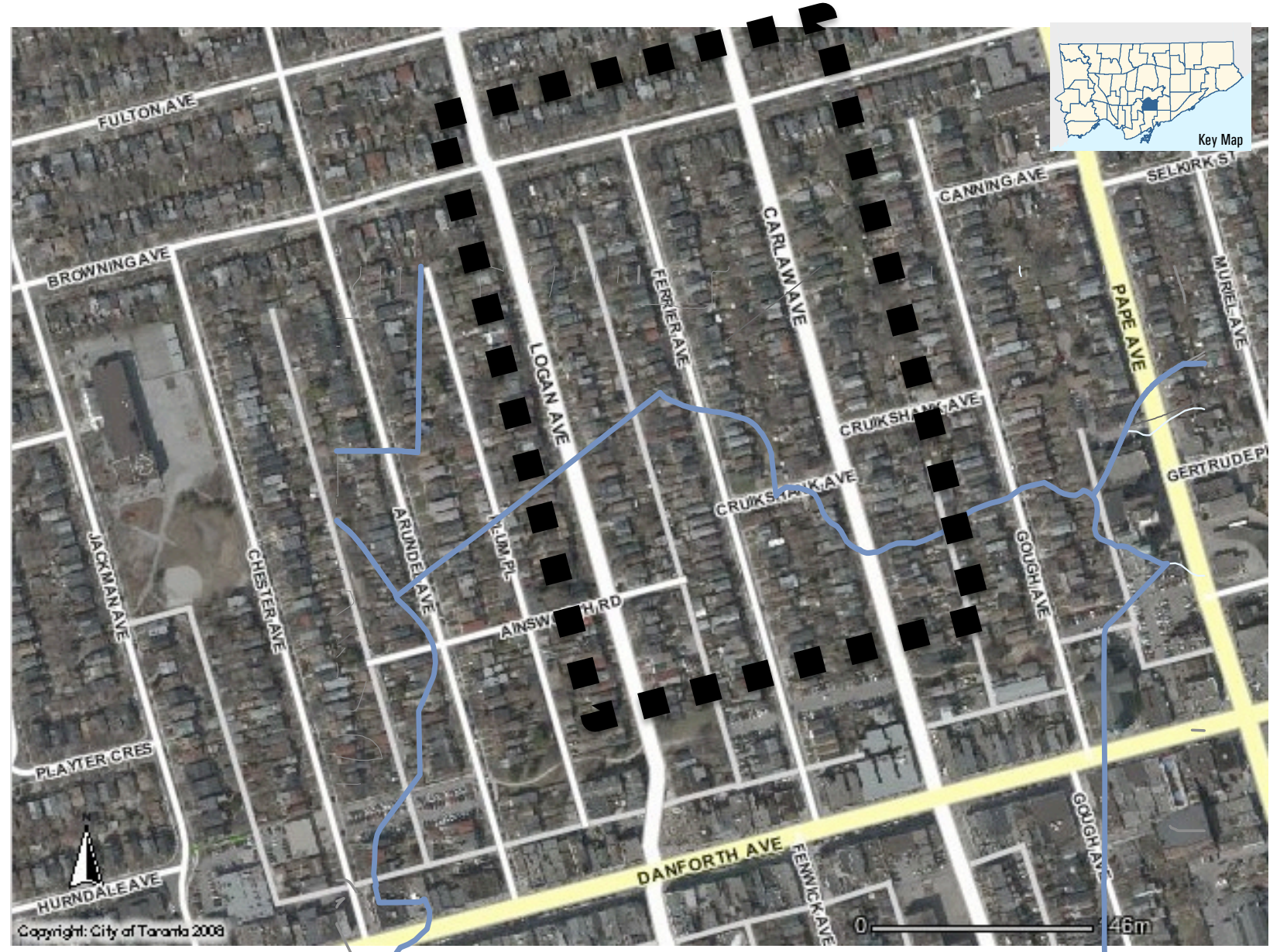



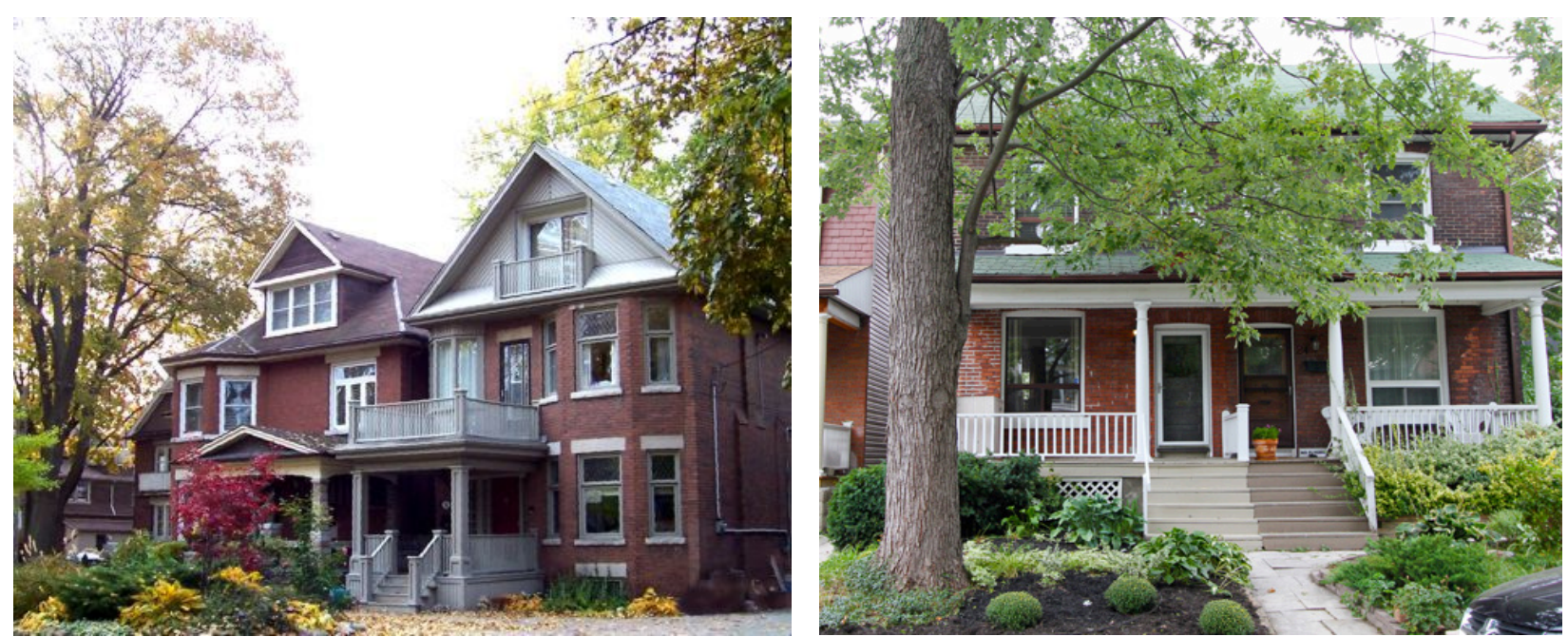

According to the 2006 Canadian Census, the Danforth neighbourhood currently exhibits the following socio-demographic statistics:

- Percentage of Renter Households: $\mathbf{5 5 \%}$

- Average Private Household income: \$61,249

- Average rent: $\$ 951$

- Renters spending $30 \%$ or more of their yearly income on rent: $\mathbf{3 9 \%}$

- Average household value: $\$ \mathbf{5 6 8 , 7 2 1}$

Within the Parking and Accessory Apartments: A Metro Toronto Case Study, the Playter EstatesDanforth neighbourhood was originally selected because of its close proximity to downtown and excellent transit.

The 2012 Assessment Roll figures are added to the result of the physical survey, the $38 \%$ of all houses with Playter Estates-Danforth neighbourhood contain at least one secondary suite. Table \#9 and Table \#10 provided below identify the number of secondary suites and summarize the degree of intensification within each housing type. 
Table \#9: The Danforth - 2012 Assessment Rolls

\begin{tabular}{|l|c|c|c|c|}
\hline Structure Code & $\begin{array}{c}\text { No. of } \\
\text { Structures }\end{array}$ & $\begin{array}{c}\text { No. of Structures } \\
\text { with Secondary } \\
\text { Suites }\end{array}$ & $\begin{array}{c}\text { Degree of } \\
\text { Intensification }\end{array}$ & $\begin{array}{c}\text { Total Number of } \\
\text { Secondary Suites }\end{array}$ \\
\hline Single Detached & 192 & 41 & $21 \%$ & 60 \\
\hline Semi-Detached & 149 & 26 & $17 \%$ & 30 \\
\hline Duplex & - & - & - & - \\
\hline Townhouse & 13 & 1 & $8 \%$ & 1 \\
\hline \hline Other & 5 & 1 & $20 \%$ & 92 \\
\hline Total & 359 & 69 & $19 \%$ & 1 \\
\hline
\end{tabular}

Table \#10: The Danforth - 2012 Assessment Rolls and Visual Survey

\begin{tabular}{|l|c|c|c|c|}
\hline Structure Code & $\begin{array}{c}\text { No. of } \\
\text { Structures }\end{array}$ & $\begin{array}{c}\text { No. of Structures } \\
\text { with Secondary } \\
\text { Suites }\end{array}$ & $\begin{array}{c}\text { Degree of } \\
\text { Intensification }\end{array}$ & $\begin{array}{c}\text { Total Number of } \\
\text { Secondary Suites }\end{array}$ \\
\hline Single Detached & 192 & 84 & $44 \%$ & 101 \\
\hline Semi-Detached & 149 & 47 & $32 \%$ & 50 \\
\hline Duplex & - & - & - & 4 \\
\hline Townhouse & 13 & 4 & $31 \%$ & 3 \\
\hline Other & 5 & 3 & $60 \%$ & 158 \\
\hline Total & 359 & 138 & $38 \%$ & \\
\hline
\end{tabular}




\section{STUDY AREA \#5: THE BEACHES}

The Beaches (or the Beach) is located on the East side of "Old" City of Toronto and is a popular tourist destination during the warm summer months. The neighbourhood is loosely delineated by Kingston Road to the North, Lake Ontario to the South, Neville Park Boulevard to the East, and Leslie Street to the West. As illustrated in the map provided below, the Beaches Study Area is composed of four residential blocks, located between Queen Street East and Lake Ontario and West of the Harris Water Treatment facility.

Originally settled in the late 1800 s and early 1900 s as a summer resort, many of the original structures were small wooden cottages and summer homes. Over the past 150 years, large Victorian and Edwardian styled semi-detached houses have gradually replaced many of these small beach houses. Recently, this process of intensification and redevelopment has sparked heated debates, as established residents perceive new residential developments as a threat to the areas traditional aesthetic.

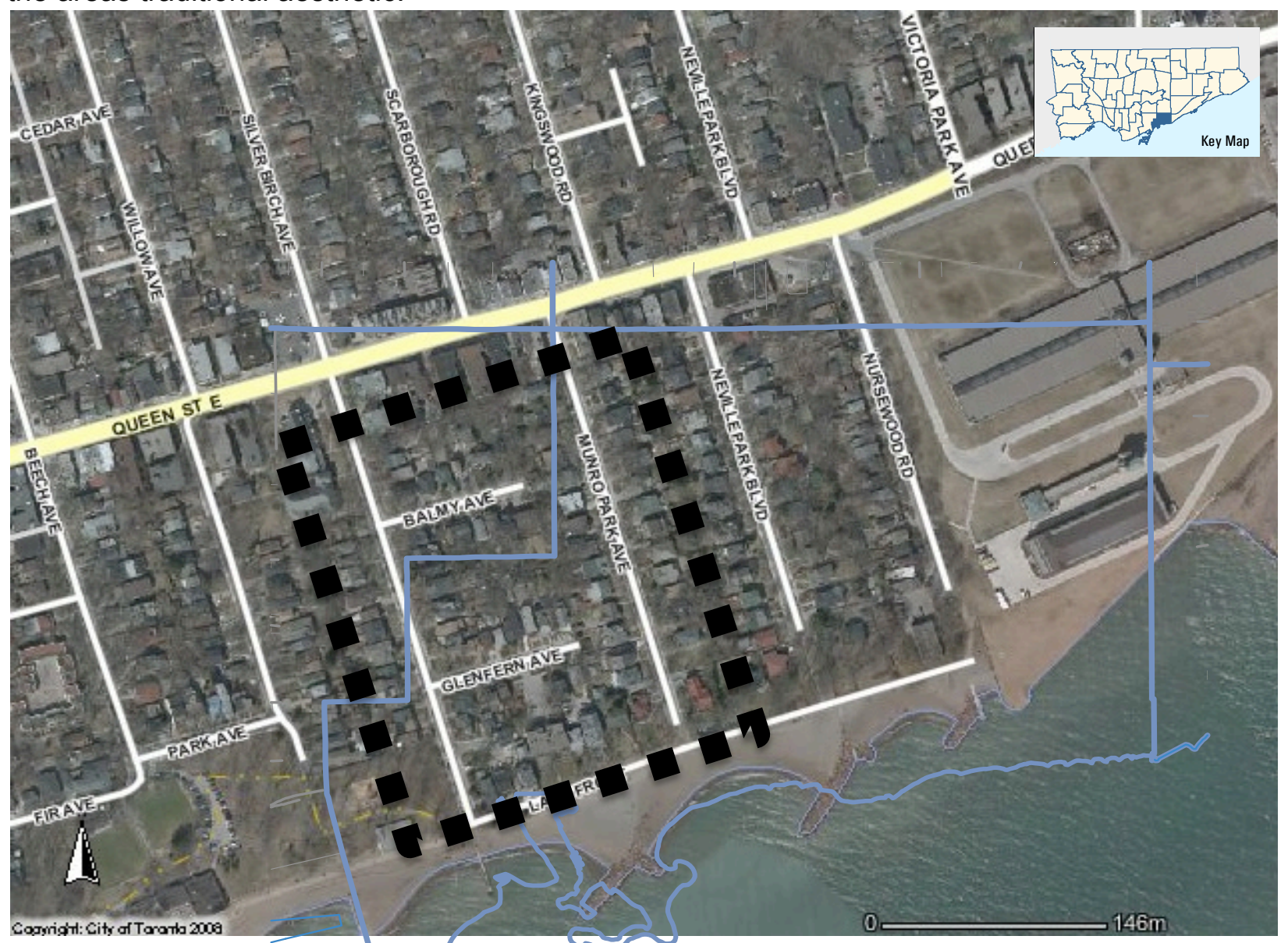



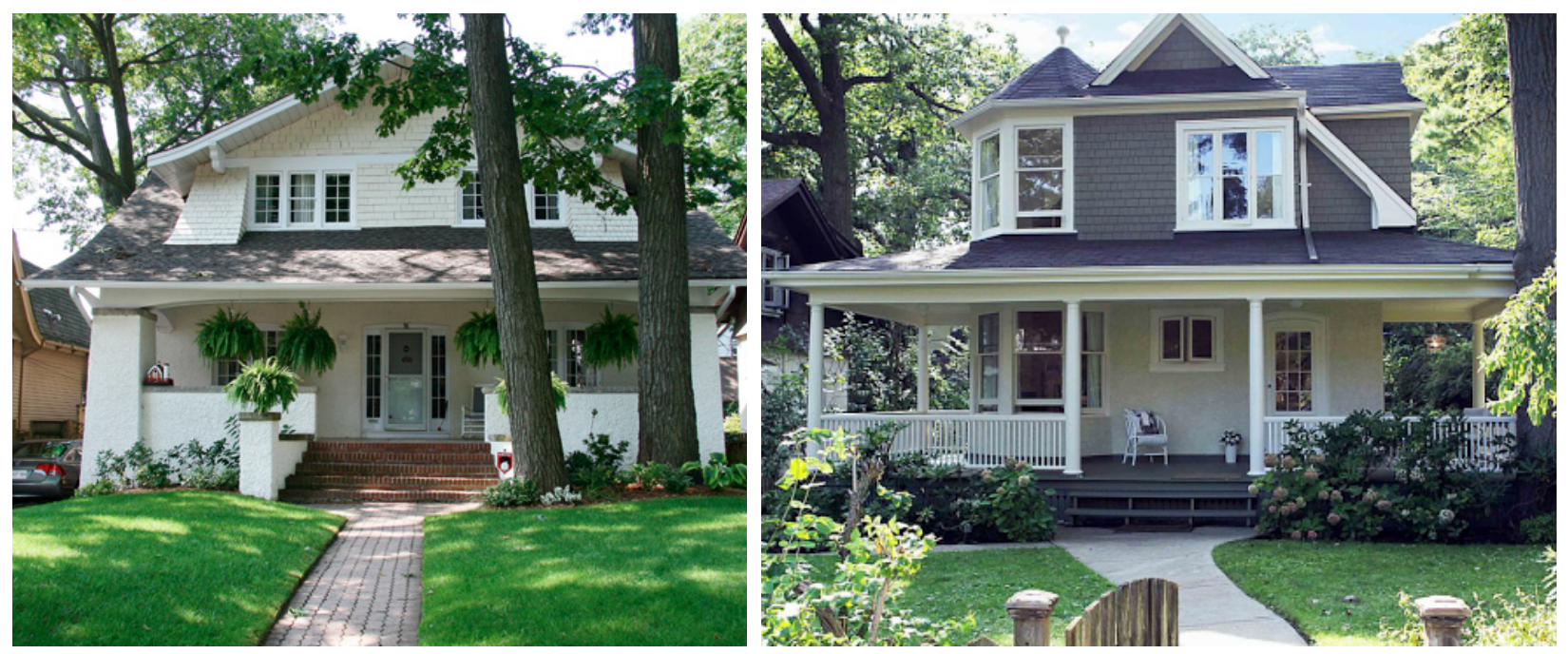

According to the 2006 Canadian Census, the Beaches neighbourhood currently exhibits the following socio-demographic statistics:

- Percentage of Renter Households: $36 \%$

- Average Private Household income: $\$ 119,634$

- Average rent: $\$ 1,032$

- Renters spending $30 \%$ or more of their yearly income on rent: $\mathbf{3 3 \%}$

- Average household value: $\$ \mathbf{7 9 9 , 0 6 4}$

According to the City of Toronto's Neighbour's Report entitled, Parking and Accessory Apartments: A Metro Toronto Case Study, the Beaches was selected "as an example of a neighbourhood with fair transit accessibility, being located on a streetcar line, but located further from the core area" (1987).

The City's 2012 Assessment Rolls indicated that 22\% of all surveyed houses contain a secondary suite, However, when these figures were combined with the results of the visual survey, it became apparent that many secondary suites within this study area are in fact unreported. Presently, $34 \%$ of all houses within the study area contain at least one secondary suite. Tables 11 and 12 provided below identify the number of secondary suites and summarize the degree of intensification within each housing type. 
Table \#11: The Beaches - 2012 Assessment Rolls

\begin{tabular}{|l|c|c|c|c|}
\hline Structure Code & $\begin{array}{c}\text { No. of } \\
\text { Structures }\end{array}$ & $\begin{array}{c}\text { No. of Structures } \\
\text { with Secondary } \\
\text { Suites }\end{array}$ & $\begin{array}{c}\text { Degree of } \\
\text { Intensification }\end{array}$ & $\begin{array}{c}\text { Total Number of } \\
\text { Secondary Suites }\end{array}$ \\
\hline Single Detached & 55 & 5 & $9 \%$ & 7 \\
\hline Semi-Detached & 11 & 0 & $0 \%$ & 0 \\
\hline Duplex & 9 & 9 & - & - \\
\hline Townhouse & - & - & $75 \%$ & 5 \\
\hline Other & 4 & 3 & $22 \%$ & 21 \\
\hline Total & 79 & 17 & & 9 \\
\hline
\end{tabular}

Table \#12: The Beaches - 2012 Assessment Rolls and Visual Survey

\begin{tabular}{|l|c|c|c|c|}
\hline Structure Code & $\begin{array}{c}\text { No. of } \\
\text { Structures }\end{array}$ & $\begin{array}{c}\text { No. of Structures } \\
\text { with Secondary } \\
\text { Suites }\end{array}$ & $\begin{array}{c}\text { Degree of } \\
\text { Intensification }\end{array}$ & $\begin{array}{c}\text { Total Number of } \\
\text { Secondary Suites }\end{array}$ \\
\hline Single Detached & 55 & 14 & $25 \%$ & 20 \\
\hline Semi-Detached & 11 & 1 & $9 \%$ & 13 \\
\hline Duplex & 9 & 9 & $100 \%$ & - \\
\hline Townhouse & - & - & - & 5 \\
\hline Other & 4 & 3 & $34 \%$ & 39 \\
\hline Total & 79 & 27 & & 13 \\
\hline
\end{tabular}




\section{STUDY AREA \#6: ROSEDALE-MOORE PARK}

Rosedale-Moore Park is Toronto's most elite neighbourhood. Located between several ravines and within close proximity to Toronto's Central Business District (CBD), the area is delineated by Moore Avenue to the North, Bloor Street East to the South, Bayview Avenue to the East, and Yonge Street to the West. As illustrated in the map provided below, the Rosemount Study Area is composed of approximately four residential blocks and bisected by Mount Pleasant Road.

As one of Toronto's oldest suburbs, Rosedale-Moore Park was first developed during the late 1800s. Due to its proximity to downtown and impressive natural features, the area was a natural location for Toronto's elite. Between 1870 and 1910, these individuals built impressive brick mansions along the area's winding tree-lined streets, many of which contain architecturally significant design elements. Over the course of nearly 150 years, the area has remained an enclave for Canada's richest and most famous citizens and, although much of the housing stock has experienced significant structural changes, these single detached homes remain iconic symbols of Toronto's past.

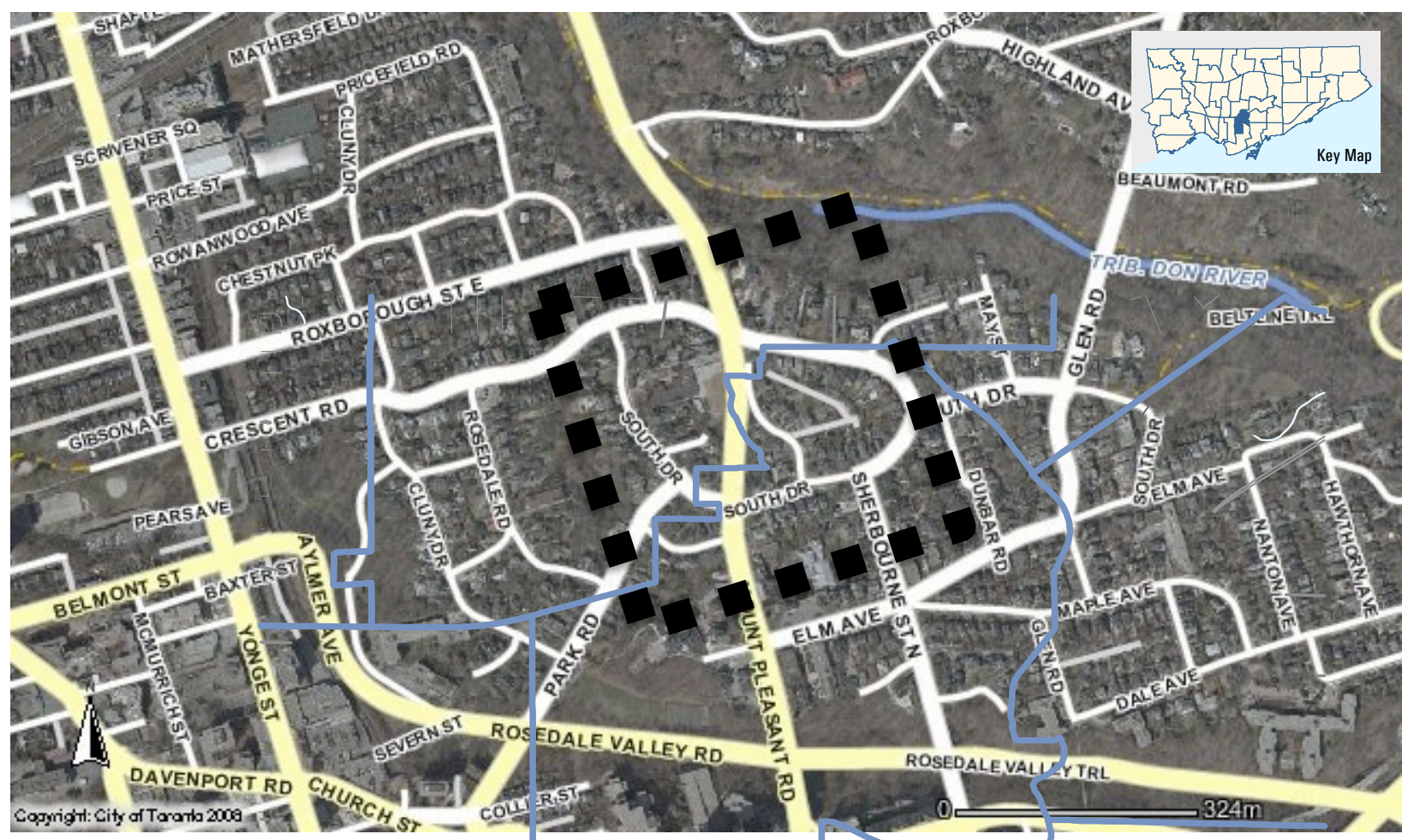



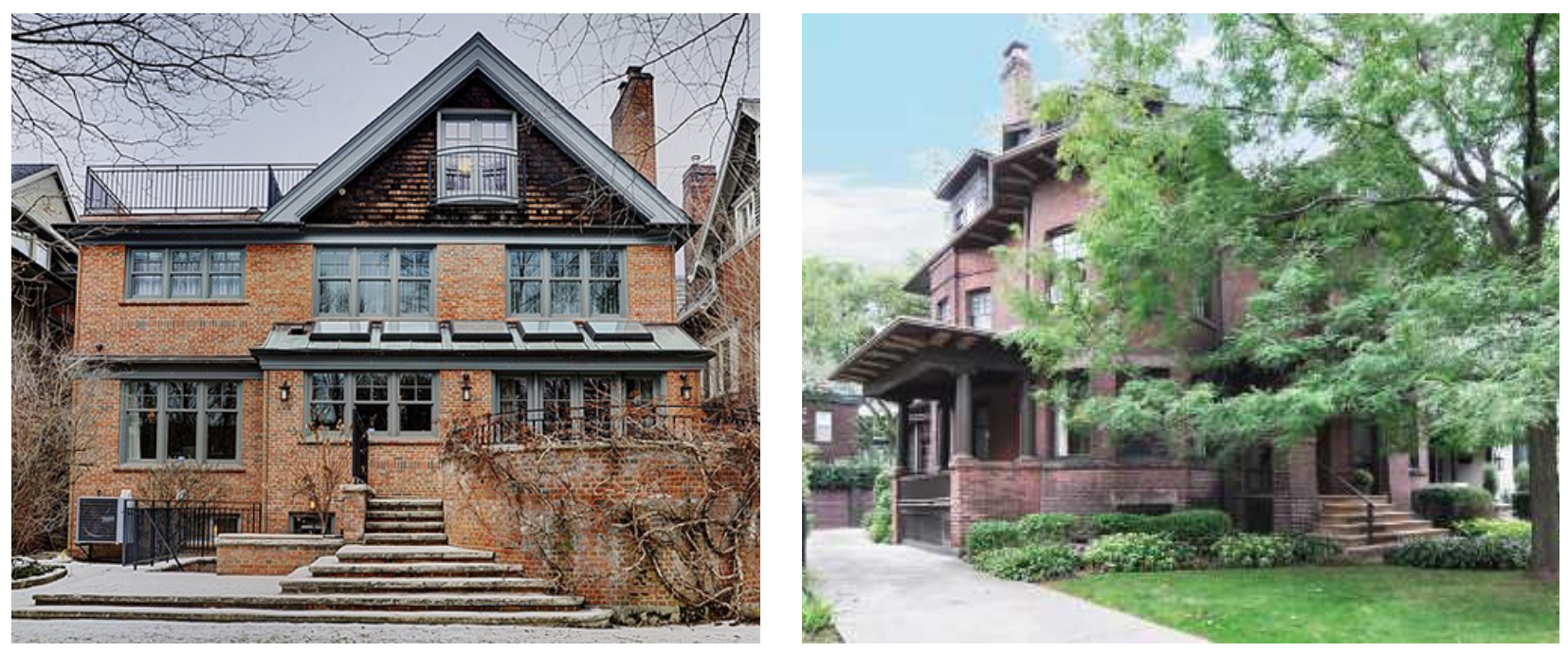

According to the 2006 Canadian Census, the Rosedale neighbourhood currently exhibits the following socio-demographic statistics:

- Percentage of Renter Households: $\mathbf{4 4 \%}$

- Average Private Household income: $\mathbf{\$ 2 4 5 , 1 4 8}$

- Average rent: $\$ 1,290$

- Renters spending $30 \%$ or more of their yearly income on rent: $\mathbf{3 1 \%}$

- Average household value: $\$ 996,079$

According to the City of Toronto's Neighbour's Report entitled, Parking and Accessory Apartments: A Metro Toronto Case Study, Rosedale was selected due to a number of physical and socio-demographic characteristics. Most notably its good transit accessibility, close proximity to downtown, and high-income households.

Presently, only $15 \%$ of single detached houses contain a secondary suite. The loss of secondary suites within this area is principally the result of rising household incomes. Tables 13 and 14 provided below identify the number of secondary suites and summarize the degree of intensification within each housing type. 
Table \#13: Rosedale-Moore Park - 2012 Assessment Rolls

\begin{tabular}{|l|c|c|c|c|}
\hline Structure Code & $\begin{array}{c}\text { No. of } \\
\text { Structures }\end{array}$ & $\begin{array}{c}\text { No. of Structures } \\
\text { with Secondary } \\
\text { Suites }\end{array}$ & $\begin{array}{c}\text { Degree of } \\
\text { Intensification }\end{array}$ & $\begin{array}{c}\text { Total Number of } \\
\text { Secondary Suites }\end{array}$ \\
\hline Single Detached & 80 & 12 & $15 \%$ & 23 \\
\hline Semi-Detached & 5 & 0 & $0 \%$ & 0 \\
\hline Duplex & 4 & 1 & $25 \%$ & 1 \\
\hline Townhouse & 3 & 0 & $0 \%$ & 4 \\
\hline Other & 5 & 3 & $60 \%$ & 28 \\
\hline Total & 97 & 16 & $16 \%$ & 0 \\
\hline
\end{tabular}

Table \#14: Rosedale-Moore Park - 2012 Assessment Rolls and Visual Survey

\begin{tabular}{|l|c|c|c|c|}
\hline Structure Code & $\begin{array}{c}\text { No. of } \\
\text { Structures }\end{array}$ & $\begin{array}{c}\text { No. of Structures } \\
\text { with Secondary } \\
\text { Suites }\end{array}$ & $\begin{array}{c}\text { Degree of } \\
\text { Intensification }\end{array}$ & $\begin{array}{c}\text { Total Number of } \\
\text { Secondary Suites }\end{array}$ \\
\hline Single Detached & 80 & 12 & $15 \%$ & 23 \\
\hline Semi-Detached & 5 & 1 & $20 \%$ & 2 \\
\hline Duplex & 4 & 2 & $50 \%$ & 0 \\
\hline Townhouse & 3 & 0 & $0 \%$ & 4 \\
\hline \hline Other & 5 & 3 & $60 \%$ & 30 \\
\hline Total & 97 & 18 & $19 \%$ & \\
\hline
\end{tabular}




\section{STUDY AREA \#7: WILLOWDALE}

Willowdale is an established, affluent community located within the former City of North York and is loosely delineated by Finch Avenue to the North, Hwy 401 to the South, Bayview Avenue to the East, and Bathurst Street to the West. As illustrated in the map provided below, the Willowdale Study Area is composed of three residential blocks, located East of Senlac Road and three blocks south of Finch Avenue West.

The Willowdale neighbourhood consists primarily of single-family homes. However, condominium townhouses and high-rise condominium towers are located along major arterial roads such as Finch Avenue or Yonge Street. The original single-family homes within the area were originally constructed around the 1950s. However, over the past several decades, the Willowdale area has experienced significant gentrification. As such, many of the modest postwar bungalows are being replaced by very large two-storey luxury homes (also known as "monster homes").

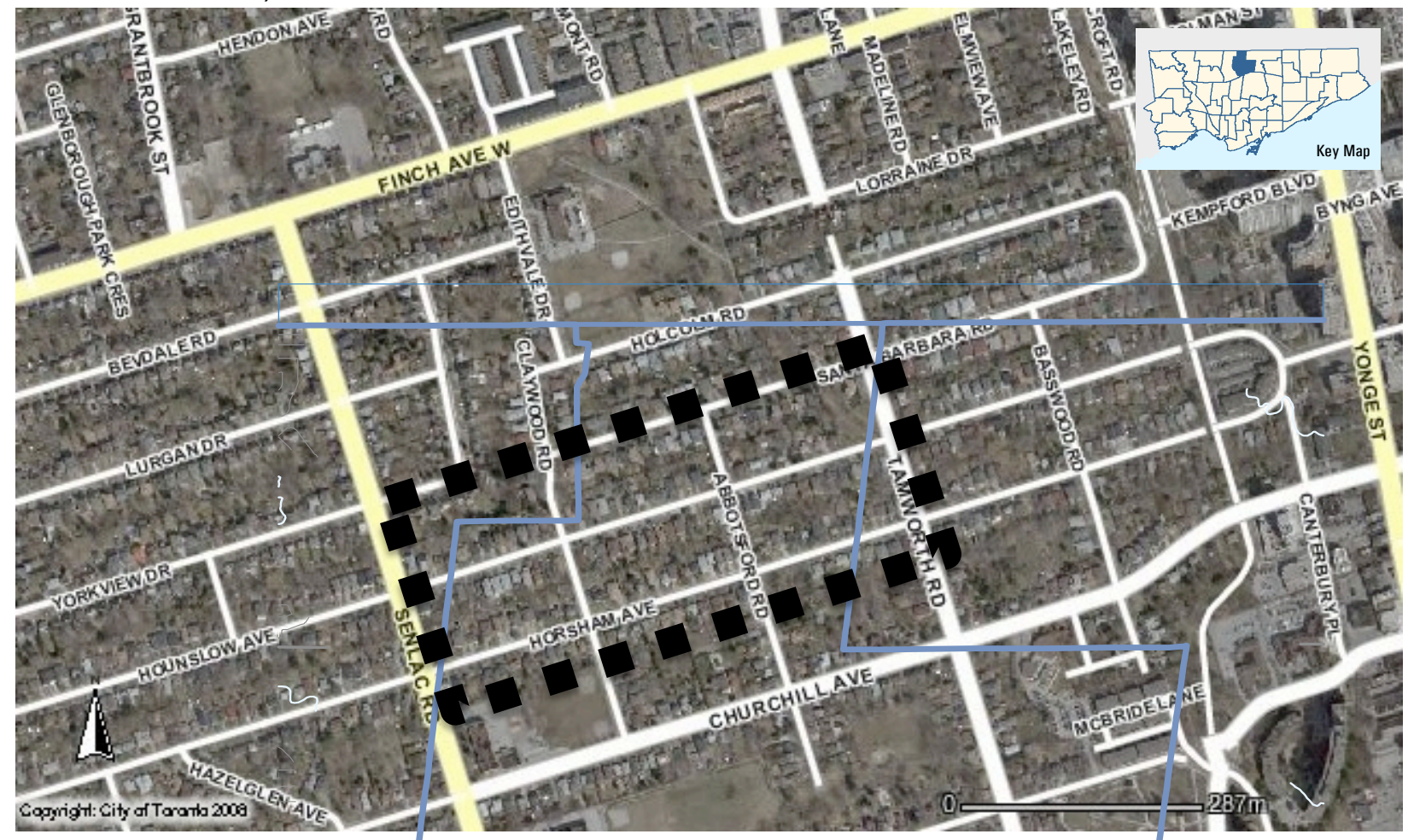



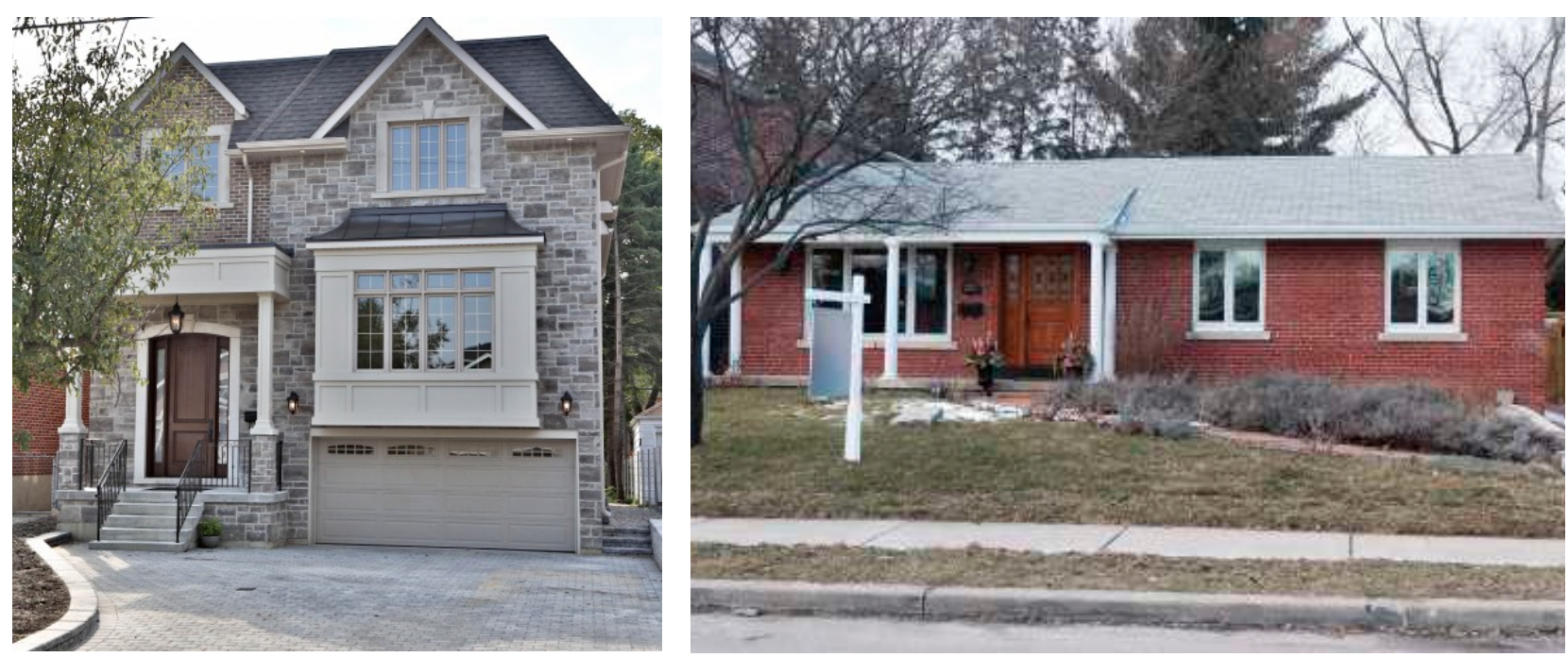

According to the 2006 Canadian Census, the Willowdale neighbourhood currently exhibits the following socio-demographic statistics:

- Percentage of Renter Households: $\mathbf{3 0 \%}$

- Average Private Household income: $\$ \mathbf{7 5 , 7 7 8}$

- Average rent: $\$ 904$

- Renters spending $30 \%$ or more of their yearly income on rent: $\mathbf{4 1 \%}$

- Average household value: $\$ \mathbf{4 2 2 , 4 7 3}$

According to the City of Toronto's Neighbour's Report entitled, Parking and Accessory Apartments: A Metro Toronto Case Study, the Willowdale Study Area (referred to as North York) was selected as an example of a typical low-density suburban neighbourhood. This area is the farthest from downtown Toronto and is less accessible by public transit than all the other study areas. While conducting the visual survey, it was very difficult to identify units with a secondary suite. The typical visual clues such as buzzers, additional mailboxes, and garbage bins were not easily observed.

While conducting the physical survey, an additional 4 single detached houses were identified as having a secondary suite for a total of 12 units. Tables 15 and 16 provided below identify the number of secondary suites and summarize the degree of intensification within each housing type. 
Table \#15: Willowdale - 2012 Assessment Rolls

\begin{tabular}{|l|c|c|c|c|}
\hline Structure Code & $\begin{array}{c}\text { No. Of } \\
\text { Structures }\end{array}$ & $\begin{array}{c}\text { No. Of Structures } \\
\text { with Secondary } \\
\text { Suites }\end{array}$ & $\begin{array}{c}\text { Degree of } \\
\text { Intensification }\end{array}$ & $\begin{array}{c}\text { Total Number of } \\
\text { Secondary Suites }\end{array}$ \\
\hline Single Detached & 142 & 8 & $6 \%$ & - \\
\hline Semi-Detached & - & - & - & - \\
\hline Duplex & - & - & - & - \\
\hline Townhouse & - & - & - & - \\
\hline Other & - & - & - & 8 \\
\hline Total & 142 & 8 & $6 \%$ & \\
\hline
\end{tabular}

Table \#16: Willowdale - 2012 Assessment Rolls and Visual Survey

\begin{tabular}{|l|c|c|c|c|}
\hline Structure Code & $\begin{array}{c}\text { No. Of } \\
\text { Structures }\end{array}$ & $\begin{array}{c}\text { No. Of Structures } \\
\text { with Secondary } \\
\text { Suites }\end{array}$ & $\begin{array}{c}\text { Degree of } \\
\text { Intensification }\end{array}$ & $\begin{array}{c}\text { Total Number of } \\
\text { Secondary Suites }\end{array}$ \\
\hline Single Detached & 142 & 12 & $8 \%$ & 12 \\
\hline Semi-Detached & - & - & - & - \\
\hline Duplex & - & - & - & - \\
\hline Townhouse & - & - & - & - \\
\hline \hline Other & - & - & - & 12 \\
\hline Total & 142 & 12 & $8 \%$ & - \\
\hline
\end{tabular}




\section{SUMMARY}

Within the seven Neighbourhoods Study Areas, a total of 1,268 residential structures were recorded within the database. Single detached and semi-detached houses were by far the most frequently recorded structure types within all seven neighbourhoods. However, most neighbourhoods also included single-family row/townhouse and duplex structure types while structure types with three or more units were observed only within select neighbourhoods. Furthermore, the physical size and number of structures of within each study area varied significantly. A number of study areas contained a sample size much smaller than the average, most notably, the Beaches and Rosedale. These neighbourhoods contained 79 and 97 residential structures respectively.

\section{Degree of Intensification}

As illustrated above, the degree of intensification varied greatly from one Study Area to next. The lowest rate of intensification observed was, not surprisingly, the Willowdale neighbourhood in North York. According to Assessment Roll data, only 8 (or 6\%) of the 142, residential structures surveyed contained at least one reported secondary suite. In addition to these units, another 4 structures with unreported suites were identified during the visual survey bringing the total to 12 $(8 \%)$.

In contrast, the Annex Neighbourhood Study Area had the highest level of intensification. As indicated within the Assessment Rolls, 89 (or 46\%) of the 195 residential structures surveyed contained at least one reported secondary suite. When these figures were added to those generated from the visual survey, the total number of reported and unreported secondary suites increased to 132 , or $68 \%$ of all structures.

In their 1987 parking study, The Ministry of Municipal Affairs and Housing suggested it was likely that between 10 to 20 percent of all single family housing in urban

municipalities had a reported or unreported secondary suite (Ontario Ministry of Housing, 1987, 7). By comparison, the average rate of intensification across all seven neighbourhoods was $25 \%$. The following two tables summarize the results for each of the seven neighbourhood areas. 
Table \#17: Degree of Intensification - Assessment Roll Data

\begin{tabular}{|c|c|c|c|}
\hline $\begin{array}{l}\text { Neighbourhood } \\
\text { Study Area }\end{array}$ & No. of Structures & $\begin{array}{c}\text { No. of Structures with } \\
\text { Secondary Suites }\end{array}$ & Degree of Intensification \\
\hline The Annex & 195 & 89 & $46 \%$ \\
\hline The Junction & 239 & 77 & $32 \%$ \\
\hline $\begin{array}{l}\text { Corsa Italia - } \\
\text { Davenport }\end{array}$ & 157 & 45 & $29 \%$ \\
\hline The Danforth & 359 & 69 & $19 \%$ \\
\hline The Beaches & 79 & 17 & $22 \%$ \\
\hline Rosedale & 97 & 16 & $16 \%$ \\
\hline Willowdale & 142 & 8 & $6 \%$ \\
\hline Total & 1,268 & 321 & $25 \%$ \\
\hline
\end{tabular}

Table \#18: Degree of Intensification - Assessment Roll Data and Visual Survey

\begin{tabular}{|l|c|c|c|}
\hline $\begin{array}{l}\text { Neighbourhood } \\
\text { Study Area }\end{array}$ & No. of Structures & $\begin{array}{c}\text { No. of Structures with } \\
\text { Secondary Suites }\end{array}$ & \begin{tabular}{c} 
Degree of Intensification \\
\hline The Annex
\end{tabular} \\
\hline The Junction & 239 & 132 & $68 \%$ \\
\hline Corsa Italia - & 195 & 113 & $47 \%$ \\
\hline Davenport & 157 & 69 & $44 \%$ \\
\hline The Danforth & 359 & 138 & $38 \%$ \\
\hline The Beaches & 79 & 27 & $34 \%$ \\
\hline Rosedale & 97 & 18 & $19 \%$ \\
\hline Willowdale & 142 & 12 & $8 \%$ \\
\hline Total & 1,268 & 509 & $40 \%$ \\
\hline
\end{tabular}

\section{Advancing Assessment Roll Estimation}

In addition to identifying the varying degrees of intensification, the results also illustrate the inherent limitations associated with assessment roll data. When using this estimation technique in isolation, the degree of intensification is severely inaccurate. The findings suggest that for every two residential structures with at least one secondary suite reported within the Assessment 
Rolls, there is on average one additional converted structure with at least one secondary suite not reported.

This gap between the assessment roll data and the revised methodological approach employed as part of this project was most noticeable within the Danforth Study Area. According to the Assessment Rolls, this neighbourhood has 69 residential structures with at least one reported secondary suite. However, when the assessment roll data was added to the results from the visual survey, this number increased to 138. Meaning, that for every one structure with a reported secondary suite identified within the assessment rolls there is one additional residential structure with an unreported secondary suite. In contrast, the Rosedale neighbourhood represents the lower end of the spectrum. Within this neighbourhood, for every eight reported conversions there is one unreported converted structure.

However, it is not possible to create similar ratios comparing the number of reported-tounreported secondary suites. In many cases, identifying the exact number of secondary suites within an unreported converted structure was not possible through a visual survey.

Table \#19: Number of Converted Structures not Reported in Assessment Rolls

\begin{tabular}{|l|c|c|}
\hline $\begin{array}{l}\text { Neighbourhood Study } \\
\text { Area }\end{array}$ & $\begin{array}{c}\text { Number of Converted Structures } \\
\text { not Reported in Assessment Rolls }\end{array}$ & $\begin{array}{c}\% \text { Increase to Assessment } \\
\text { Roll Estimates }\end{array}$ \\
\hline The Annex & 43 & $48.3 \%$ \\
\hline The Junction & 36 & $46.7 \%$ \\
\hline Corsa Italia - Davenport & 25 & $53.3 \%$ \\
\hline The Danforth & 70 & $100 \%$ \\
\hline The Beaches & 10 & $59 \%$ \\
\hline Rosedale & 2 & $12.5 \%$ \\
\hline Willowdale & 4 & $50 \%$ \\
\hline Total & 188 & $58.6 \%$ \\
\hline
\end{tabular}

\section{Average number of Secondary Suites per Converted Structure}

Lastly, the data collected within this report also sheds light on the average number of secondary suites per converted dwelling. Similar to the degree of intensification and ratio of reported-tounreported units previously identified, the average number of secondary suites per converted structure varies significantly. According to the assessment rolls, on average each converted structure has 1.62 secondary suites. The highest average, as expected, was observed in the 
Annex where the average converted structure has 2.15 secondary suites. In contrast, a converted structure in Willowdale is likely to contain only one secondary suite.

Table \#20: Average Number of Secondary Suites per Converted Structure Reported in Assessment Rolls

\begin{tabular}{|l|c|c|c|}
\hline $\begin{array}{l}\text { Neighbourhood } \\
\text { Study Area }\end{array}$ & $\begin{array}{c}\text { No. of Structures with } \\
\text { Secondary Suites }\end{array}$ & $\begin{array}{c}\text { Total Number of } \\
\text { Secondary Suites }\end{array}$ & $\begin{array}{c}\text { Average Number of } \\
\text { Secondary Suites per } \\
\text { Structure }\end{array}$ \\
\hline The Annex & 89 & 192 & 2.15 \\
\hline The Junction & 77 & 104 & 1.35 \\
\hline Corsa Italia - & 45 & 75 & 1.66 \\
\hline Davenport & 69 & 92 & 1.33 \\
\hline The Danforth & 17 & 21 & 1.23 \\
\hline The Beaches & 16 & 28 & 1.75 \\
\hline Rosedale & 8 & 8 & 1 \\
\hline Willowdale & 321 & 520 & 1.62 \\
\hline Total & & & \\
\hline
\end{tabular}

Table \#21: Average Number of Secondary Suites for Converted Structures Reported in Assessment Rolls and Identified through Visual Surveys

\begin{tabular}{|l|c|c|c|}
\hline $\begin{array}{l}\text { Neighbourhood } \\
\text { Study Area }\end{array}$ & $\begin{array}{c}\text { No. of Structures } \\
\text { with Secondary } \\
\text { Suites }\end{array}$ & $\begin{array}{c}\text { Total Number of } \\
\text { Secondary Suites }\end{array}$ & $\begin{array}{c}\text { Average Number of } \\
\text { Secondary Suites per } \\
\text { Structure }\end{array}$ \\
\hline The Annex & 132 & 275 & 2.08 \\
\hline The Junction & 113 & 148 & 1.30 \\
\hline Corsa Italia - & 69 & 106 & 1.54 \\
\hline Davenport & 138 & 158 & 1.14 \\
\hline The Danforth & 27 & 39 & 1.44 \\
\hline The Beaches & 18 & 30 & 1.67 \\
\hline Rosedale & 12 & 12 & 1 \\
\hline Willowdale & 509 & 768 & 1.5 \\
\hline Total & & & \\
\hline
\end{tabular}


The average number of secondary suites per converted dwelling actually decreased when applying the results from the visual surveys to those generated from the assessment rolls alone. This observation was found in all seven Neighbourhood Study Areas. As illustrated in Table \#21, the average number of secondary suites per converted dwelling is 1.5 . 


\section{Chapter 6: Number of Secondary Suites in Toronto}

\section{INTRODUCTION}

Moving forward, it seemed fitting to apply the results generated from the selected estimation techniques at a citywide scale in order to estimate the entire secondary suite rental market. Although the estimates illustrated within this chapter rely on a relatively crude methodological approach, it is anticipated that they will provide valuable insight for government agencies nonetheless. Based on the 2013 assessment rolls and informed by the visual survey results, the following tables illustrate the various steps taken to estimate the number of the secondary suites within the City of Toronto.

\section{STEP \#1: NUMBER OF CONVERTED STRUCTURES BY PROPERTY CODE}

As illustrated in Table \#22, there are currently 22,148 single, semi, and row houses within the City of Toronto that have experienced intensification through conversion. Through a simple comparison of an address's property and structure codes, it is relatively easy to identify the presence of a secondary suite. For example, when a single, semi or row house transitions from a structure with one residential unit to a structure within two or more units, the newly assigned property code records the intensification process. It is also worth mentioning that, located within these 22,148 converted structures, are 30,158 reported secondary suites.

\section{Table \#22: Number of Converted Structures}

\begin{tabular}{|l|c|c|}
\hline Property Code & Number Converted Structures & Number of Secondary Suites \\
\hline Two self-contained units & 16,235 & 16,235 \\
\hline Three self-contained units & 4,502 & 9,004 \\
\hline Four self-contained units & 952 & 2,856 \\
\hline Five self-contained units & 267 & 1,068 \\
\hline Six self-contained units & 157 & 785 \\
\hline Multi-Residence, more than 6 & 35 & $210 *$ \\
\hline self-contained units & & 30,158 \\
\hline Total
\end{tabular}

Source: 2013 Assessment Data generated by the City of Toronto Planning Division 
STEP \#2: NUMBER OF SINGLE, SEMI, ROW AND DETACHED STRUCTURES WITH BASEMENT APARTMENTS

In addition to Property Code and Structure Code comparisons, MPAC's assessment roll variable basement apartment also identifies the presence of a secondary suite. The basement apartment variable is found in nearly every residential type. As illustrated in Table 23, there are 28,517 single, semi, and row houses with a basement apartment. If all other structure types are added to this figure, the total number of residential structures with a basement apartment is 32,392 . To date, no other report using assessment roll data has included this variable within their estimates.

Table \#23: Number of Basement Apartments in Single, Semi and Row Structures

\begin{tabular}{|c|c|c|c|c|}
\hline \multirow[b]{2}{*}{ Property Code } & \multicolumn{3}{|c|}{ Structure Code } & \multirow[b]{2}{*}{ Total } \\
\hline & $\begin{array}{l}301 \\
\text { Single family } \\
\text { detached }\end{array}$ & $\begin{array}{l}302 \\
\text { Single family } \\
\text { semi-detached }\end{array}$ & $\begin{array}{l}303 \\
\text { Single family } \\
\text { row house }\end{array}$ & \\
\hline $\begin{array}{l}301 \text { - Single family } \\
\text { detached }\end{array}$ & 16,865 & 23 & 2 & 16,890 \\
\hline $\begin{array}{l}309 \text { - Townhouse/row } \\
\text { house }\end{array}$ & 0 & 6 & 494 & 500 \\
\hline 311 - Semi-detached & 12 & 4,452 & 4 & 4,468 \\
\hline $\begin{array}{l}332 \text { - Residential } \\
\text { structure with two self- } \\
\text { contained units }\end{array}$ & 1,479 & 1,205 & 211 & 2,895 \\
\hline $\begin{array}{l}333 \text { - Residential } \\
\text { structure with three self- } \\
\text { contained units }\end{array}$ & 944 & 1,647 & 256 & 2,847 \\
\hline $\begin{array}{l}334 \text { - Residential } \\
\text { structure with four self- } \\
\text { contained units }\end{array}$ & 356 & 248 & 27 & 631 \\
\hline $\begin{array}{l}335 \text { - Residential } \\
\text { structure with five self- } \\
\text { contained units }\end{array}$ & 112 & 44 & 7 & 163 \\
\hline $\begin{array}{l}336 \text { - Residential } \\
\text { structure with six self- } \\
\text { contained units }\end{array}$ & 94 & 19 & 1 & 114 \\
\hline $\begin{array}{l}340 \text { - Multi-residential, } \\
\text { with } 7 \text { or more self- } \\
\text { contained units }\end{array}$ & 7 & 2 & 0 & $9 *$ \\
\hline Total & 19,869 & 7,646 & 1,002 & 28,517 \\
\hline
\end{tabular}

Source: 2013 Assessment Data generated by the City of Toronto Planning Division 
However, these results need to be viewed with caution as duplication may have occurred between Step \#1 and Step \#2. Although duplication is only possible within approximately 10,000 addresses (due to the fact that 21,858 addresses identified within this step have the same property and structure code and, were therefore, not identified in Step \#1), it is believed that these results are fairly accurate. While using assessment roll data at the neighbourhood level, it was evident that these two variables are in fact relatively exclusive and do not overlap in most instances. However, further research is warranted.

\section{STEP \#3: NUMBER OF CONVERTED STRUCTURES WITHIN ASSESSMENT ROLLS}

To estimate the number of converted structures within the City of Toronto it is necessary to combine the results from Table \#22 to those within Table \#23. According to the 2013 assessment rolls there are currently 54,540 legally converted structures within the City. Again, these results must be reviewed with caution as some level of duplication may have occurred between Step \#1 and Step \#2.

\section{STEP \#4: NUMBER OF CONVERTED STRUCTURES NOT WITHIN ASSESSMENT ROLLS}

In order to estimate the total number of converted structures within the City of Toronto, it is necessary to identify the number of converted structures not recorded in MPAC's assessment rolls. To accomplish this task, the reported-to-unreported structure ratios developed within the previous chapter were applied to the total number of reported converted structure identified above. According to the results generated from the seven Neighbourhood Study Areas, for every two reported converted structures there is, on average approximately one unreported converted structure. However, in order to account for neighbourhood diversity, three scenarios are needed - high, medium and low. As illustrated within Table \#24, the estimated number of unreported converted structures not identified within MPAC's assessment rolls ranges between 5,450 to 27,270 structures.

Table \#24: Number of Converted Structures not Reported within Assessment Rolls

\begin{tabular}{|c|c|c|c|}
\hline Forecast & $\begin{array}{c}\text { Number Reported Converted } \\
\text { Structures }\end{array}$ & $\begin{array}{l}\text { Average Ratio of } \\
\text { Reported to Unreported } \\
\text { Converted Structures }\end{array}$ & $\begin{array}{l}\text { Number of Unreported } \\
\text { Converted Structures }\end{array}$ \\
\hline Low & 54,540 & $10: 1$ & 5,450 \\
\hline Medium & 54,540 & $4: 1$ & 13,635 \\
\hline High & 54,540 & $2: 1$ & 27,270 \\
\hline
\end{tabular}




\section{STEP \#5: TOTAL NUMBER OF CONVERTED STRUCTURES}

To estimate the total number of converted structures, both legal and illegal, the results from Step \#3 were added to those generated in Step \#4. As illustrated in Table \#25, there are between 59,990 and 81,810 converted structures within the City of Toronto

\section{Table \#25: Total Number of Converted Structures}

\begin{tabular}{l} 
Forecast \\
\hline Low \\
\hline Medium \\
\hline High
\end{tabular}

\begin{tabular}{|c|c|c|}
\hline $\begin{array}{c}\text { Number Reported } \\
\text { Converted Structures }\end{array}$ & $\begin{array}{c}\text { Number of Unreported } \\
\text { Converted Structures }\end{array}$ & Total \\
\hline 54,540 & 5,450 & 59,990 \\
\hline 54,540 & 13,635 & 68,175 \\
\hline 54,540 & 27,270 & 81,810 \\
\hline
\end{tabular}

\section{STEP \#6: NUMBER OF SECONDARY SUITES}

Lastly, in order to estimate the total number of secondary suites within the City of Toronto, the figures illustrated in Table \#25 were multiplied by an average number of units per structure. According to the Neighbourhood Study Areas, there is on average approximately 1.5 secondary suites per converted dwelling. However, it is believed that this figure is slightly inflated. As such, the 2013 assessment roll average of 1.25 was applied instead. According to these calculations, it is believed that the number of secondary suites in the City of Toronto is between 74,988 and 102,263 . Table \#26 provides a summary of these calculations.

Table \#26: Total Number of Secondary Suites

\begin{tabular}{|c|c|c|c|}
\hline Forecast & $\begin{array}{c}\text { Total Number of } \\
\text { Converted Structures }\end{array}$ & $\begin{array}{l}\text { Average Number of Units } \\
\text { per Converted Structures }\end{array}$ & $\begin{array}{l}\text { Total Number of } \\
\text { Secondary Suites }\end{array}$ \\
\hline Low & 59,990 & 1.25 & 74,988 \\
\hline Medium & 68,175 & 1.25 & 85,219 \\
\hline High & 81,810 & 1.25 & 102,263 \\
\hline
\end{tabular}




\section{Chapter 7: Recommendations}

After a thorough review of the results generated from the applied estimation techniques and upon reflection of the developed methodological approach, a number of important findings emerged. Although it is recommended that the City of Toronto's Planning Division adopt a similar methodology to the one employed within this report, there are several concerns that need to be discussed and addressed. Moving forward, it is possible to further refine the methodological approach identified within this report in order to increase the overall accuracy and reliability of the secondary suite estimates. The following section will briefly describe these findings.

\section{RECOMMENDATION \#1: IMPROVING VISUAL SURVEY RESULTS}

While conducting the visual surveys for each Neighbourhood Study Area, it became apparent that this technique was not capable of accurately identifying the exact number of secondary suites within a converted structure. Although most of the converted structures were easily identified, clearly distinguishing a structure with one secondary suite from a structure with three was, in many cases, extremely difficult. Furthermore, as the number of illegal suites within a converted structure increased, so too did the level of subjectivity. Consequently, many secondary suites within converted houses with two or more units may not have been recorded in the neighbourhood databases.

In response to this methodological limitation, it is thought that a door-to-door survey could be added to the visual survey to improve or verify the results. In 1991, the City of Toronto conducted a study on secondary suites entitled, Neighbours: Project Pilot, which combined visual and doorto-door surveys to gather qualitative information regarding secondary suites. It is believed that this survey method could be used on an address-by-address basis in order to provide additional information for clarification purposes. The data collected during the door-to-door surveys could then be incorporated into a shared database, improving the reliability and accuracy of secondary suite estimations.

\section{RECOMMENDATION \#2: TORONTO SECONDARY SUITE SURVEY}

Since 1983, the City of Toronto's Strategic Initiatives, Policy, and Analysis Division has conducted an annual survey of businesses in an effort to monitor the City's economic health as well as aiding in decision and policy making. Each summer, over twenty student surveyors collect vital data from individual business establishments and record the number of full or part employees, type of business, and other important variables (City of Toronto, 2013). This 
background information helps policy makers forecast and plan the City's infrastructure and services for the citizens and businesses of Toronto.

Similar to the Toronto Employment Survey, the City could also conduct visual surveys much like the one employed within this report to identify secondary suites. During the summer months, a team of two or three students could easily conduct several hundred neighbourhood studies across the city. The large sample size would permit an in depth analysis of both the reported and unreported aspects of the secondary suite rental market. With accurate data, housing analysts and researchers could finally understand the size, strength, and locational and distributional characteristics of the entire secondary rental housing market. If conducted on a yearly basis, additional observations could be made regarding the number of illegal units that move in and out of the secondary rental market. In addition, this data could also be used, much like the employment survey, to forecast and plan the City's infrastructure and services for the citizens and businesses.

\section{RECOMMENDATION \#3: CLARIFY AND IMPROVE MPAC DATA VARIALBES}

While becoming immersed in the property assessment rolls, it became apparent that past studies, have not realized the full potential of MPAC's database. These studies ran the variables Structure Code and Property Codes against each other to identify the number of additional units added to a structure since the time of its original construction. But they did not consider or were not aware of the data variable basement type, which specifically identifies a basement apartment. It is believed that the variable basement apartment was overlooked because, unlike the methodological approach used within the project, their approach did not require manually entering each address into the MPAC database. It is also possible that MPAC may have enhanced the information collected over the past decade.

To improve the overall usability of MPAC data, some level of dialogue between municipal planners and assessment roll collectors must finally take place. It is believed that additional variables could be added to the information collected by property assessment agents and that this information could be provided in a much more user friendly manner.

\section{RECOMMENDATION \#4: INCORPORATE MLS DATA}

The data collected during the neighbourhood surveys could be further enhanced with the inclusion of Multiple Listing Services data. Presently, MLS informally collects data on secondary suites. It is believed that their data could provide valuable insight on unreported converted 
structures, helping to bridge the current information gap that exists regarding this aspect of the secondary suite rental market.

\section{RECOMMENDATION \#5: ESTIMATE DECONVERSIONS}

Since the secondary suites are relatively unregulated by government agencies, these units move freely in and out of the rental market. In many cases, the decision to create and/or rent a secondary suite is in response to general trends within the housing and rental markets. When vacancy rates are extremely low and homeownership becomes less affordable, low- to mediumincome homeowners are more likely to rent out unused or underutilized spaces within their homes. However, the opposite is also true. When vacancy rates are above $3 \%$ and home mortgage payments are affordable, the overall size of the secondary rental market shrinks.

Unfortunately, the methodological approach employed within the report did not attempt to consider the process of deconversion. In order to account for such losses, a randomized telephone survey could be combined with other estimation techniques, including visual surveys and assessment roll searches. Through a randomized telephone survey, a predetermined number of addresses within the created database could be randomly selected. These households could then be contacted to verify whether or not the secondary suite was currently being rented. The percentage of households indicating that their secondary suite was not longer being rented out could then be applied to the estimations generated though other techniques, resulting in a more accurate picture of the secondary suite rental market.

\section{RECOMMENDATION \#6: COMPARISONS}

Even though a significant amount of research has been done on secondary suites, comparisons are often not possible due to conflicting estimating technique. As of yet, no standard research methodology has been adopted. Moving forward, government agencies need to develop a standardized approach to provide yearly comparisons. These comparisons would allow for additional monitoring and highlight particular concerns within the City's rental housing market. 


\section{Chapter 8: Conclusion}

The role of secondary suites within the City of Toronto's cannot be understated. These units provide affordable and accessible housing for thousands of low- to medium income renters, while also providing much-needed rental income for homeowners. They are part of an overall solution to address housing affordability within the City of Toronto. As such, their presence should be acknowledged, promoted, and encouraged within every neighbourhood across the City and in all appropriate building typologies.

Over the past several decades, various government agencies and housing researchers have attempted to uncover the size, strength and characteristics of both the reported and unreported aspects of the secondary suite rental housing market, Their efforts have required them to utilize a whole host of estimation techniques within their research methodologies. The most notable of these studies was completed in 2004 by SHS consulting. Their thorough study attempted to estimate the size of the entire secondary suite rental market and identify a whole host of characteristic associated with this housing type, including average rent and size. Their estimations have been the foundation of our current understanding of secondary suites within the City of Toronto.

However, not much research has been accomplished since 2004. As such, our estimates and understanding of secondary suites is extremely limited. In response to these concerns, this report attempted to bridge a number of information gaps and sought to answer a number of fundamental questions related to the size and strength of the secondary suite rental market. This process unearthed a number of very interesting results. Most notably related to the actual number of units that currently exist within the City of Toronto. According to the employed methodological approach, there are currently between 74,988 and 102,263 secondary suites within the City. Understanding all aspects of the housing market is essential. Focusing on certain segments of the housing or rental market does not make sense given the heterogeneity within the City current housing stock. This is particularly true when it is abundantly clear that many of these unregulated segments of the rental market are now playing a more prominent role within the City of Toronto. 


\section{Bibliography}

Affordable Housing and Choice Today (ACT) Project (2003). Second Suites Promotion.

Association of Municipalities of Ontario, (1992). AMO's Response to Apartments in Houses.

Canadian Urban Institute, (1994). Perspectives on Apartments in Houses: Will it be an Effective Intensification Strategy?

City of Brampton (2012). Basement Apartments: History of Basement Apartments in Brampton.

Retrieved from http://www.brampton.ca/en/residents/By-Law-Enforcement/Pages/

Basement-Apartments.aspx.

City of Etobicoke (1988). Etobicoke Housing Statement Background Report \#3: Potential Housing Supply and Residential Conversion.

City of Toronto. (2006). Profile Toronto: Rental Housing Supply and Demand Indicators.

Retrieved from http://www.toronto.ca/planning/pdf/housing_rental.pdf

City of Toronto. (2013). Annex Neighbourhood Profile. Retrieved from www.toronto.ca/demographics/cns_profiles/cns95.htm.

City of Toronto. (1987). Parking and Accessory Apartments: A Metro Toronto Case Study.

City of Toronto. (1991). Neighbours' Pilot Project.

City of Toronto. (2006). Perspectives on Housing Affordability. Retrieved from http://www.toronto.ca/planning/pdf/housing_afford.pdf

City of Toronto (2006). The City of Toronto Official Plan. Retrieved from http://www.toronto.ca/planning/official_plan/pdf_chapter1-5/chapters1_5_dec2010.pdf

City of Toronto (1999). By-Law No. 446-1999.

City of Toronto. (1999). City of Toronto Community Services Report: Proposed "Add-A-Suite" Incentive Program.

City of Toronto (1999). Planning and Transportation Committee Report: Draft Official Plan Amendments and Zoning By-Law Amendments to Permit Second Suites As-of-Right.

City of Toronto (2013). Toronto Employment Survey. Retrieved from http://www.toronto.ca/demographics/surveys.htm 
City of Toronto (2006). Perspectives on Housing Affordability. Retrieved from http://www.toronto.ca/planning/pdf/housing_afford.pdf.

CMHC (2006). Research Highlight: Accessory Apartment Regulations in Census Metropolitan Areas in Canada. Socio-economic Series.

CMHC (2001). Research Highlight: The Impact of Municipal User Fees on Secondary Suites. Socio- economic Series 91.

CMHC (1999). Research Report: The Impact of Secondary Suites on Municipal Infrastructure and Service.

CMHC (1999). How the District of North Vancouver Built Community Acceptance for the Legalization of Secondary Suites in Single Family Neighbourhoods.

CMHC. (1990). Accessory Apartments: Characteristics, Issues, Opportunities.

CMHC (2012). Frequently Asked Question: Affordable Housing. Retrieved from www.cmhcschl.gc.ca/en/corp/faq/faq_002.cfm

Dennis (n.d). The Planning Act: A Source Book Third Edition. Retrieved from http://www.woodbull. ca/pub/Former_Sourcebook_Editions/3rdEditionofSourcebookAppendix\%20F.PDF

Gunn, A., Cater, T., and Osborne J. (2009). The Secondary Suite Rental Market: A Literature Review and Case Study. Retrieved from http://geograph.uwinnipeg.ca/Carter/Publications/Journals/Secondary -Rental-Market.pdf Hare, P. and Ostler, J. (1987). Creating an Accessory Apartment: For Every Homeowner Who Want to Turn Extra Space into Extra Income. Mcgraw-Hill Book Company, New York. Housing Choices. (2011). Mississauga's Affordable Housing Strategy and Action Plan Human Resources and Skill Development Canada (2012). Housing Rental Vacancy Rates. Retrieved from www.hrsdc.gc.ca.

Kitchen, H. (2002). Municipal Revenue and Expenditure Issues in Canada, Canadian Tax Paper No. 107, Canadian Tax Foundation, Toronto.

Metropolitan Washington Council of Governments. (1981). Accessory Apartments: A Local Housing Alternative. 
Murdie, R. and Northrup, D. (1990). Residential Conversion in Toronto: The Availability of Rental Units in the Owner Occupied Dwellings in the City of Toronto

Ontario, Ministry of Municipal Affairs and Housing (2011). Bill 140: The Strong Communities through Affordable Housing Act (2011)

Ontario, Ministry of Municipal Affairs and Housing (2009). Canada-Ontario Affordable Housing Program: New Rental Housing Component.

Ontario, Ministry of Municipal Affairs and Housing (2012). Provincial Policy Statement Review: Under the Planning Act.

Ontario, Ministry of Municipal Affairs and Housing (1982). Making Better use of Existing Housing Stock: A Literature Review. Prepared by: J Hulchanski.

Ontario, Ministry of Public Infrastructure Renewal. Places to Grow: Where and How to Grow Policies.

Ontario, Ministry of Housing (1994). Apartments in Houses Municipal Guide. Retrieved from http://www.mah.gov.on.ca/Asset8884.aspx?method=1

Ontario, Ministry of Housing (1988). Housing Policy Statement: Implementation Guidelines.

Ontario. (1990). Ontario Planning Act.

Ontario, Ministry of Housing. (1994). Apartments in Houses: A Consultation Paper on Legislative Amendments to Allow One Apartment in a House.

Ontario, Ministry of Housing. (1987). Parking and Accessory Apartments: A Metro Toronto Case.. Ontari, Ministry of Municipal Affairs and Housing. (2005). Provincial Policy Statement.

Ponasa Real Estate Investments. (n.d.). MLS Search. Retrieved from http://ponasa.propertyware.com/

Ramserran, S. (1990). Accessory Apartments in the Homes of Seniors: A New Housing Strategy. University of Manitoba.

Richard Drdla and Associates. (1988). Potential Housing Supply and Residential Conversion: Final Report.

Rudel, T. (1994). Household Change, Accessory Apartments, and Low Income Housing in Suburbs. Professional Geographer, 36(2): 174-181. 
Social Housing Strategists Inc. (2004). City of Toronto Second Suites (Accessory Apartments)

Review.

Statistics Canada. (2010). 2006 Community Profiles. Retrieved from

http://www12.statcan.ca/census- $\quad$ recensement/2006/dp-pd/prof/92-

591/details/Page.cfm?Lang $=E \& G e 01=P R \& C o d e 1=35 \& G e o 2$

$=P R \&$ Code $2=01 \&$ Data $=$ Count $\&$ Search Text=Ontario $\&$ SearchType=Begins $\&$ SearchPR $=$ $01 \& B 1=$ All\&GeoLevel=PR\&GeoCode $=35$

The Starr Group. (2000). Secondary Rental Market Study: Final Report.

Toronto Neighbourhood Guide. (2013). Toronto Neighbourhood Map. Retrieved from http://www.torontoneighbourhoods.net/

Toronto Neighbourhoods. ( 2013). Midtown: Annex. Retrieved from www.torontoneighbourhoods.net/neighbourhoods/midtown/annex.

Toronto Neighbourhoods. ( 2013). Playter Estates-Danforth. Retrieved from http://www.torontoneighbourhoods.net/neighbourhoods/east-end/playterestates/historyWood, Dennis (n.d). The Planning Act: A Source Book Third Edition. Retrieved from http://www.woodbull.ca/pub/Former_Sourcebook_Editions/3rdEditionofSourcebookAppen dix\%20F.PDF

\section{Neighbourhood Study Area Maps}

City of Toronto. (2013). T.O. Inview - 2013. Retrieved February 15, 2013 from: http://map.toronto.ca/maps/map.jsp?app=TO_INview2013

City of Toronto. (n.d.). Toronto Neighbourhood Maps. Retrieved February 15, 2013 from http://www.toronto.ca/demographics/profiles_map_and_index.htm

\section{Neighbourhood Study Area Photos}

Canada Property Listings. (2013). No Title. Retrieved February 15, 2013 from:

http://www.canadaproperty listing.com/5-bedroom-House-for-Rent-in-30-LAUDER-AVEToronto,-ON-M6H-3E3-pid845258s2 
Core Realty Group Inc. (n.d.) Annex. Retrieved February 15, 2013 from:

http://www.corerealtygroupinc.com/go/en/neighbourhoods/annex/

Heaps and Estrin Sales Representatives. (2013). The Pocket at Danforth and Jones. Retrieved

February $\quad$ 15, 2013 from: http://heapsestrin.com/2012/09/vibrant-pocket-of-danforth-andjones/

Leader Post. (2012). Photos: Buy this fancy South Rosedale home in Toronto for $\$ 6.25 \mathrm{M}$.

Retrieved February 15, 2013 from:

http://www.leaderpost.com/homes/Gallery+Coveted+South

+Rosedale+home+Toronto/7970552/story.html

Mark Loeffler Team. (n.d.) 322 Horsham Avenue. Retrieved February 15, 2013 from:

http://markloefflerteam.ca/ListingNotFound.aspx?lid=28611155

Rebecca Laing. (n.d.). Playter Estates Homes. Retrieved February 15, 2013 from:

http://www.rebeccalaing.ca/Playter_Estates_Real_Estate

it Off. (n.d.). 38 Munro Park Avenue. Retrieved February 15, 2013 from:

http://www.showitoff.ca/38munropark/

Select Homes for Sale. (2010). The Junction. Retrieved February 15, 2013 from:

http://www.selecthomesforsale.com/neighbourhood/the-junction/

Slavens and Associates. (n.d.) 269 Horsham Avenue. Retrieved February 15, 2013 from: http://www.slavensrealestate.com/?p=9524

Sotheby's International Realty. (n.d.) 131 South Drive. Retrieved February 15, 2013 from: http://www.trilogyagents.com/listings.php?listing=LL620132

The Mash. (2012). 44 Munro Park Avenue - THE BEACHES. Retrieved February 15, 2013 from: http://themashcanada.blogspot.ca/2012/09/44-munro-park-beaches.html

The Torontolist. (n.d.) 131 South Drive, Toronto - House for Sale. Retrieved February 15, 2013 from

http://thetorontolist.com/toronto-property-for-sale-fd.php?pid=737

View Toronto Homes. (n.d.). The Junction. Retrieved February 15, 2013 from:

http://www.viewtorontohomes.com/The_Junction_real_estate 